\title{
Um modelo de ocupação regional Guarani no sul do Brasil
}

\author{
Rafael Guedes Milheira*
}

MILHEIRA, R.G. Um modelo de ocupação regional Guarani no sul do Brasil. Revista do Museu de Arqueologia e Etnologia, São Paulo, 18: 19-46, 2008.

Resumo: Este artigo apresenta um estudo de arqueologia regional, buscando entender as relações sistêmicas de ocupação Guarani na margem sudoeste da Laguna dos Patos e a Serra do Sudeste - RS. A partir de uma abordagem regional e levando em consideração as condições locais de conservação, este estudo foca na distribuição regional de sítios, suas estruturas internas e conjuntos artefatuais. Para entender padrões de ocupação territorial e distribuição do assentamento arqueológico, a sistematização das análises tecno-tipológicas, a composição dos sítios arqueológicos e as informações etnográficas e etnohistóricas permitiram constituir um panorama histórico de longa duração, revelando estratégias de manutenção de redes sociais Guarani e contatos inter-culturais num domínio de território que se articula entre os distintos estratos ambientais da região.

Palavras-chave: Arqueologia Guarani - Arqueologia regional - Sistema de assentamento - Território de domínio - Organização social.

\section{Introdução}

O presente trabalho é o resultado parcial de um amplo projeto arqueológico, intitulado Projeto de Mapeamento Arqueológico de Pelotas e Região (PMAPR), desenvolvido desde o ano de 2001 pelo Laboratório de Ensino e Pesquisa em Antropologia e Arqueologia da Universidade Federal de Pelotas (LEPAARQ-UFPEL), sob coordenação do Prof. Dr. Fábio Vergara Cerqueira. ${ }^{1}$

${ }^{*}$ ) Doutorando pelo Museu de Arqueologia e Etnologia (MAE-USP). Pesquisador associado ao Laboratório de Ensino e Pesquisa em Antropologia e Arqueologia da Universidade Federal de Pelotas (LEPAARQ-UFPel). <milheirarafael@gmail.com> (1) Este trabalho é um resumo da dissertação Território e Estratégia de Assentamento Guarani na Planície Sudoeste da Laguna dos Patos e Serra do
Este projeto arqueológico visa o mapeamento de vestígios das diferentes ocupações humanas na região que abrange o município de Pelotas e municípios vizinhos, desde as mais antigas populações que habitaram a região, como é o caso dos grupos construtores de cerritos e grupos Guarani, até as ocupações mais recentes, desenvolvidas já no período póscolonial, que configuram o panorama histórico atual. ${ }^{2}$
Sudeste - RS. Parte deste texto já foi publicada em Milheira (2007a), cabendo aqui algumas considerações mais atualizadas.

(2) A pesquisa foi desenvolvida sob a orientação da Profa. Dra. Elaine Hirata (MAE-USP), contando com o apoio do Conselho Nacional de Desenvolvimento Científico e Tecnológico - CNPq. 


\section{Revisão bibliográfica e objetivos de pesquisa}

A arqueologia Guarani na região da Laguna dos Patos e Serra do Sudeste é objeto de pesquisa desde os anos 40 , sob vários olhares e perspectivas teóricas diferenciadas (Métraux 1948; Pernigotti e Almeida 1961; Naue, Schmitz e Basile-Becker 1968; Naue et al. 1971; Brochado 1974; Schmitz 1976; Carle 2002; Ribeiro et al. 2004; Rogge 2004; Pestana 2007). Diversos pesquisadores realizaram seus estudos ao longo dos terrenos charcosos, em meio às planícies das lagoas e sobre os campos abertos da paisagem lacustre. Por outro lado, também foram percorridos os vales, arroios, córregos e morros do Escudo Rio-grandense, também conhecido como Serra do Sudeste ou mesmo Serra dos Tapes. Alguns destes pesquisadores, preocupados em localizar e registrar os passos das sociedades indígenas na região foram pioneiros na identificação de dezenas de sítios arqueológicos, contribuindo para um panorama de ocupação históricocultural que ainda hoje se destaca pelas discussões propostas. Buscaram diagnosticar a diversidade cultural pré-histórica em nível regional, se valendo dos conceitos de tradições e fases para caracterizar estas diferenças e, com isto, propor cronologias e distribuição espacial das culturas ao longo do território litorâneo e serrano.

No entanto, embora haja uma extensa tradição em pesquisas na região, ao elaborarmos nosso trabalho, ficou bastante claro o quanto o olhar destes arqueólogos sobre a ocupação regional dos grupos Guarani se limitou à mera descrição dos sítios arqueológicos, assim como sua localização espacial, alguns dados e comparações referentes à tecnotipologia cerâmica e sua cronologia de ocupação. Estes estudos se basearam, em primeira análise, em uma perspectiva empiricista e diacrônica da arqueologia, sem levar em consideração aspectos sistêmicos de ocupação regional. Com isto, queremos dizer que a arqueologia desenvolvida na porção meridional da Laguna dos Patos e Serra do Sudeste não abarca discussões mais amplas sobre territorialidade, organização social e relação entre diferentes áreas de assentamento, pois percebe os sítios arqueológicos como assentamentos isolados, ao contrário do que se conhece sobre a ocupação e as noções de território Guarani (ver Noelli 1993; Soares 1997). Neste sentido, os sítios arqueológicos Guarani foram objeto de estudos assistemáticos e superficiais, tendo sido pensados como registro de migrações oriundas do interior para o litoral (de oeste para leste) e do litoral sul para o litoral norte, formadas por grupos reduzidos em termos de demografia que ocuparam o espaço rapidamente.

Ao identificar esta lacuna na perspectiva teórica da arqueologia Guarani na região, optamos em partir de uma abordagem em que se percebessem os sítios arqueológicos como áreas de ocupações integradas, fazendo parte de um sistema de assentamento que se articula entre vários compartimentos paisagísticos (Binford 1980; Shapiro 1984; Fish \& Kowalewsky 1990; Fish 1999; Dias 2003). Buscamos então a composição de um modelo regional de ocupação Guarani em que se levaram em consideração as noções de padrão e sistema de assentamento, função de sítio, território de domínio e estratégias de assentamento. Para a composição do modelo de ocupação Guarani que se articula entre serra e litoral, partimos então a um mapeamento regional de sítios arqueológicos que permitisse diagnosticar não somente a diversidade de culturas arqueológicas, mas também a intensidade de ocupação espacial efetuada pelos grupos Guarani. Seguiu-se às intervenções intra-sítio que permitiram inferir sobre aspectos de intensidade de ocupação local, a partir do que se pôde refletir sobre aspectos da organização social Guarani, função de sítio etc..

Do ponto de vista teórico, buscamos articular conceitos da Arqueologia Regional, abordagem esta que tem sido amplamente discutida e testada em diferentes regiões e contextos arqueológicos, consistindo numa das principais ferramentas para o estudo de áreas pouco pesquisadas.

Objetivamos com a aplicação de um enfoque regional preencher uma lacuna de 
modelos regionais de ocupação indígena, questão esta ressaltada por Araujo (2001:1) ao comentar que: "A Arqueologia brasileira permanece carente de estudos regionais sistemáticos para que se torne um corpo sólido de conhecimentos. A acumulação de dados na disciplina ainda se faz de maneira assistemática, grandes áreas permanecem desconhecidas do ponto de vista arqueológico, e até mesmo a simples seqüência cronológica de acontecimentos, que constitui a base para se construir hipóteses e aplicar teorias, é ainda falha". A perspectiva de pensar regionalmente os sítios permitiu então uma aproximação da pesquisa com os pressupostos teóricos da Arqueologia Regional que foi: "conceitualmente definida por Willey (1953), como 'padrões de assentamento', aprimorada por Winters (1986) para 'sistemas de assentamento' e posteriormente difundida por pesquisadores que buscavam aproximar a relação existente entre natureza, tecnologia e sistema social" (Morales 2005: 64). Segundo Morais (1999-2000: 202) "padrão de assentamento é a distribuição de sítios arqueológicos em determinada área geográfica, refletindo as relações das comunidades do passado com o meio ambiente e as relações entre elas próprias no seu contexto ambiental (Yoffe e Sherratt 1997). Estratégias de subsistência, estruturas politicas e sociais e densidade da população foram alguns dos fatores que influenciaram a distribuição do povoamento, desenhando os padrões de assentamento". Uma dos objetivos centrais da Arqueologia Regional é a preocupação em entender os sistemas regionais de ocupação humana ${ }^{3}$ estabelecidos na paisagem, que são influenciados por estratégias econômicas, estruturas políticas e sociais, densidade populacional, estruturas simbólicas etc. (Fish \& Kowalewsky 1990; Morais 1999. 2000).

Buscamos, com a composição de um modelo de ocupação, entender aspectos históricos da cultura Guarani, articulando, contrapondo e complementando fontes arqueológicas, etnográficas

(3) "A coordenação entre sítios ou conjuntos de sítios de certa região, demonstrando relações concomitantes por contemporaneidade, similaridade ou complementaridade, define um sistema regional de povoamento" (Morais 1999-2000: 202). e etnohistóricas, o que permite estabelecer analogias etnográficas para interpretar o registro arqueológico (Brochado 1984; Noelli 1993; Soares 1997). Em última análise, estamos em busca de uma história indígena de longa duração, que se desenvolve através de processos culturais ao longo de dezenas de gerações em centenas de anos. Trata-se de abarcar questões ainda não discutidas na arqueologia da região da Laguna dos Patos e Serra do Sudeste, que permitirão avançar por sobre a arqueologia histórico-classificatória (cf. Noelli 1999-2000), propondo-se um fazer arqueológico que percebe uma continuidade entre a história Guarani de antes e depois do contato com as populações européias (Brochado 1984; Fausto 2001; Noelli 1993; Soares 1997; Neves 1999; Heckenberger \& Franchetto 2001).

\section{Metodologia de pesquisa}

A pesquisa foi desenvolvida através do método de Levantamento Arqueológico por Amostragem Probabilística Estratificada ou Sampling, que se caracteriza pela realização de levantamentos arqueológicos sistemáticos em áreas amostrais delimitadas, abrangendo todos os estratos ambientais. Foi determinada uma área piloto de $\left(9.600 \mathrm{~km}^{2}\right)$, que é pensada como o recorte paisagístico e territorial a ser estudado e que abrange grande parte da porção meridional da laguna dos Patos e da serra do Sudeste. Dentro dessa área piloto foram definidas unidades amostrais, tanto na serra como no litoral com dimensões entre $0,25 \mathrm{~km}^{2}$ até $37 \mathrm{~km}^{2}$, onde foram realizados efetivamente os trabalhos de campo, através da articulação de técnicas relativas ao método de levantamentos probabilísticos e oportunísticos e método de múltiplos estágios (Redman 1973; Araujo 2001; Dias 2003).

Como resultado imediato dos levantamentos de campo foram identificados no litoral da laguna sete sítios Guarani, sendo que três destes já haviam sido identificados por pesquisas anteriores e, devido ao forte impacto urbano causado nos últimos 40 anos, estes sítios se apresentam com um potencial de pesquisa muito limitado (PSG-17-Las Acácias, PP-01-Hospital e 
PS-01-Arroio Sujo). ${ }^{4}$ Destes sete sítios identificados, apenas quatro deles se tornaram objeto de pesquisa efetiva, dado seu grau de conservação que se traduz em um significativo potencial de pesquisa a ser explorado. Trata-se de dois sítios que se localizam na Ilha da Feitoria (PT-01-Sotéia e PT-05-Lagoinha), outro na margem da Laguna e outros dois na Praia do Totó, denominados PS. 02-Camping e PS-03-Totó, assentados sobre pequenas elevações em meio à mata de restinga.

$\mathrm{Na}$ Serra do Sudeste foram identificados outros treze sítios Guarani, sendo três situados na região da Colônia Maciel, próximos do Morro Farroupilha, denominados de Sítio Tico-Tico, Sítio da Escultura e Sítio do seu Maneco. Os outros dez sítios Guarani foram localizados nas proximidades do vale do arroio Andrade e arroio Correntes, próximos do morro dos Três Cerros e denominados Sítios Magalon 1, Magalon 2, Sítio Dummer, Sítio PSGPA-03-Rutz, PSGPA-01-Sítio Raffi 1, Raffi 2, Sítios PSGPA-02-Schwanke 1, Schwanke 2, Sítio PSGPA-04-Ribes e Sítio Fouchi (ver na Fig. 1 o mapa da área piloto e unidades amostrais). As intervenções arqueológicas nos sítios identificados, realizadas tanto no litoral como na serra, possibilitaram delimitar a área de ocupação de cada sítio, identificar estruturas arqueológicas em superfície e/ou sub-superfície, concentrações cerâmicas, coleta de vestígios para análise tecno-tipológica e coleta de amostras para datação que permitiram a obtenção de um quadro cronológico baseado em datações absolutas. Com isto, pudemos abordar questões específicas de cada sítio como a função desses enquanto elementos inseridos em um sistema de assentamento mais amplo e a intensidade de ocupação - se permanente ou semi-permanente.

Dados arqueológicos: apresentando o contexto

Apresentamos aqui alguns dados empíricos específicos de cada sítio que sofreu intervenção

(4) Estes três sítios foram identificados e estudados anteriormente por Schmitz (1966, comunicação pessoal) e Brochado (1974) (ver mais detalhes do trabalho realizado por estes pesquisadores em Milheira (2007a, 2008). arqueológica. Objetivamos, com isto, apresentar as particularidades de cada contexto arqueológico que dizem respeito aos aspectos composicionais: dimensão do sítio, características dos vestígios arqueológicos, gráficos de registro e análise de materiais e interpretações funcionais dos sítios. A partir desses dados é que poderemos extrapolar a abordagem sistêmica desde o micro-espaço do sítio até o macro-espaço, referente ao território de domínio.

\section{Sítios do Litoral}

A Planície Costeira corresponde à Bacia Sedimentar Litorânea, baixa e plana. É onde se situa a margem ocidental da Laguna dos Patos, que teve sua formação durante o quaternário através de um Sistema Deposicional de Leques Aluviais e do acréscimo de quatro Sistemas Deposicionais do tipo Laguna-Barreira (Radam Brasil 1986; Tomazelli \& Villwock 2000). Com alturas médias entre 1 e $10 \mathrm{~m}$, a planície litorânea é banhada pelas águas da Laguna dos Patos que é um importante corpo aqüífero da Planície Costeira com predominância de água "doce", embora com um significativo índice de salinização no verão. Além disso, é um grande criadouro de várias espécies aquáticas e, conseqüentemente, um grande atrativo para as atividades de pesca desde a ocupação dos sistemas socioculturais préhistóricos até tempos modernos.

Os sítios do litoral apresentaram semelhanças quanto à implantação na paisagem, pois todos os sítios se situam em meio à mata de restinga e próximos de banhados e campo aberto, além de estarem diretamente voltados para as águas da Laguna. Localizam-se em terrenos suavemente elevadiços, formados por areias quartzosas que são o registro de transgressões e regressões das águas desta laguna ou, no caso dos sítios Hospital e Las Acácias, em elevações mais proeminentes na paisagem formadas por dunas fósseis. Dos sete sítios identificados no litoral, apenas quatro deles se tornaram objeto efetivo de pesquisa gerando resultados que serão rapidamente apresentados abaixo. 


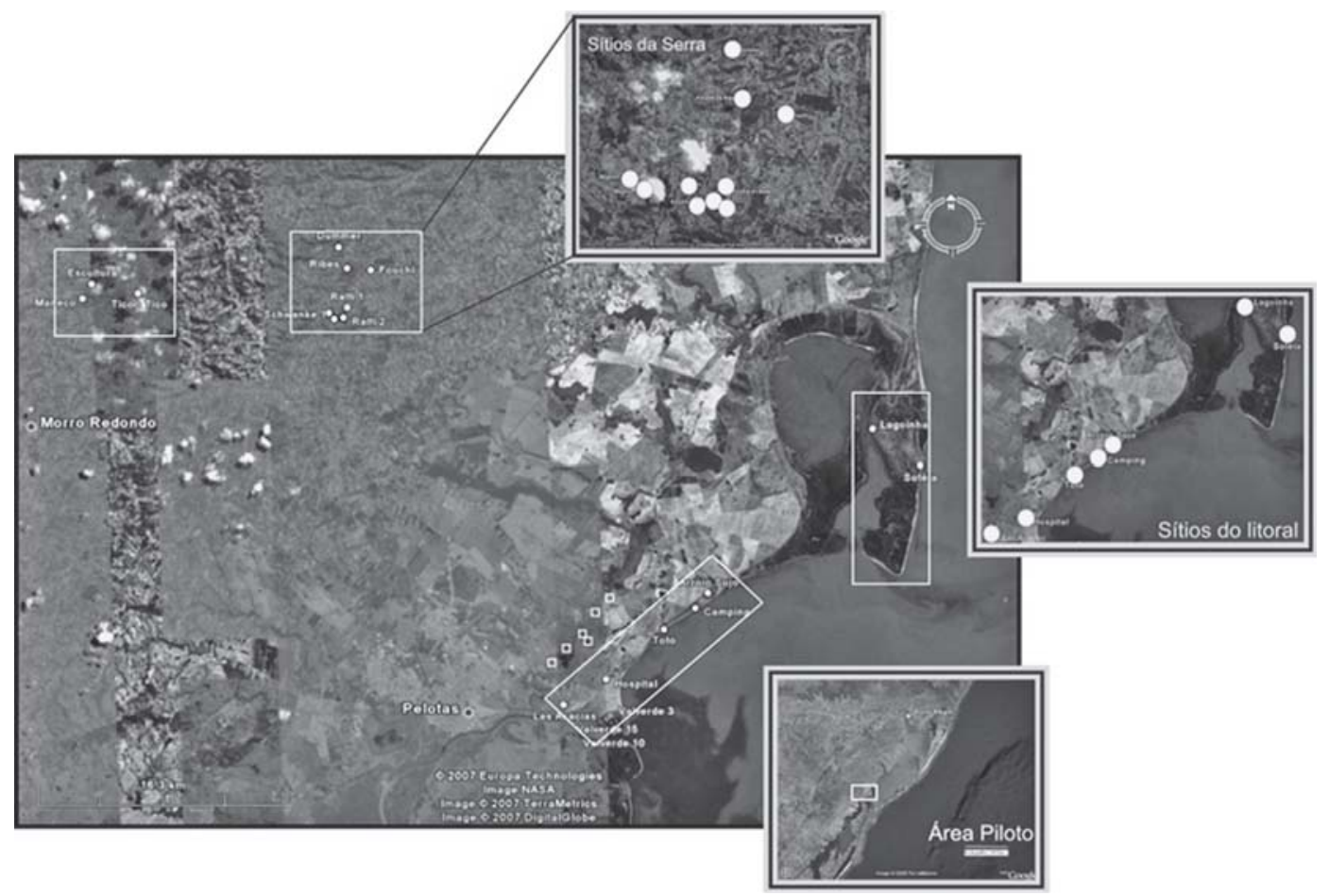

Fig. 1. Área piloto com as unidades amostrais de levantamento arqueológico. Elaboração: Rafael Milheira. Fonte: Google Earth.

\section{PT-01-Sotéia}

O sítio PT-01-Sotéia localiza-se na margem leste da Ilha da Feitoria, a aproximadamente 200 metros da margem (ver na Fig. 2 o trabalho de sondagens no sítio Sotéia). É um sítio em que predominam os vestígios cerâmicos ( 168 fragmentos de paredes de vasilhas cerâmicas e 16 bordas, totalizando 184 fragmentos) e apenas 27 artefatos líticos, sendo na sua maioria artefatos brutos sem marcas de uso, em quartzo, sem ocorrência de vestígios faunísticos. $O$ conjunto cerâmico demonstrou uma predominância de peças com a superfície externa alisada $(98,36 \%)$ e apenas $(2,71 \%)$ de peças com decoração plástica. A projeção das vasilhas cerâmicas através das bordas possibilitou a identificação de apenas duas vasilhas do tipo ñaetá. ${ }^{5} \mathrm{O}$ conjunto cerâmico do sítio remonta a potes de pequenas dimensões, com espessuras de paredes que predominam entre 8 e $10 \mathrm{~mm}$ e diâmetros de borda entre 12 e $36 \mathrm{~cm}$, porém sem ser possível saber, em sua totalidade, a que tipo de potes correspondem.

As sondagens realizadas ao longo do sítio não evidenciaram nenhum tipo de estrutura arqueológica como estrutura arquitetônica, de combustão, funerária ou de deposição de refugos em sub-superfície. É importante ressaltar que não foram poucas as sondagens, pois foram realizados 80 poços testes com pá, escavados em níveis artificiais de $10 \mathrm{~cm}$ de profundidade e 50 $\mathrm{cm}$ de lado, espaçados em 20 metros um do outro, formando um " $\mathrm{T}$ " sobre o terreno. Materiais arqueológicos foram identificados somente através das coletas de superfície sistemá-
(5) Várias referências foram utilizadas para projeção de bordas e vasilhas, assim como para interpretação da forma e função dos potes, dos quais se destaca La Salvia \& Brochado (1989); Bochado, Monticelli e Neumann (1990); Brochado \& Monticelli (1994); Jacobus (1994);
Soares (2005) e Jacques (2007). Também foram consultadas para análise dos materiais cerâmicos as obras de Rye (1981); Shepard 1985 [1956]; Robrahn-Gonzalez (1988); Orton, Tyers e Vince (1993) e Araujo (2001). 


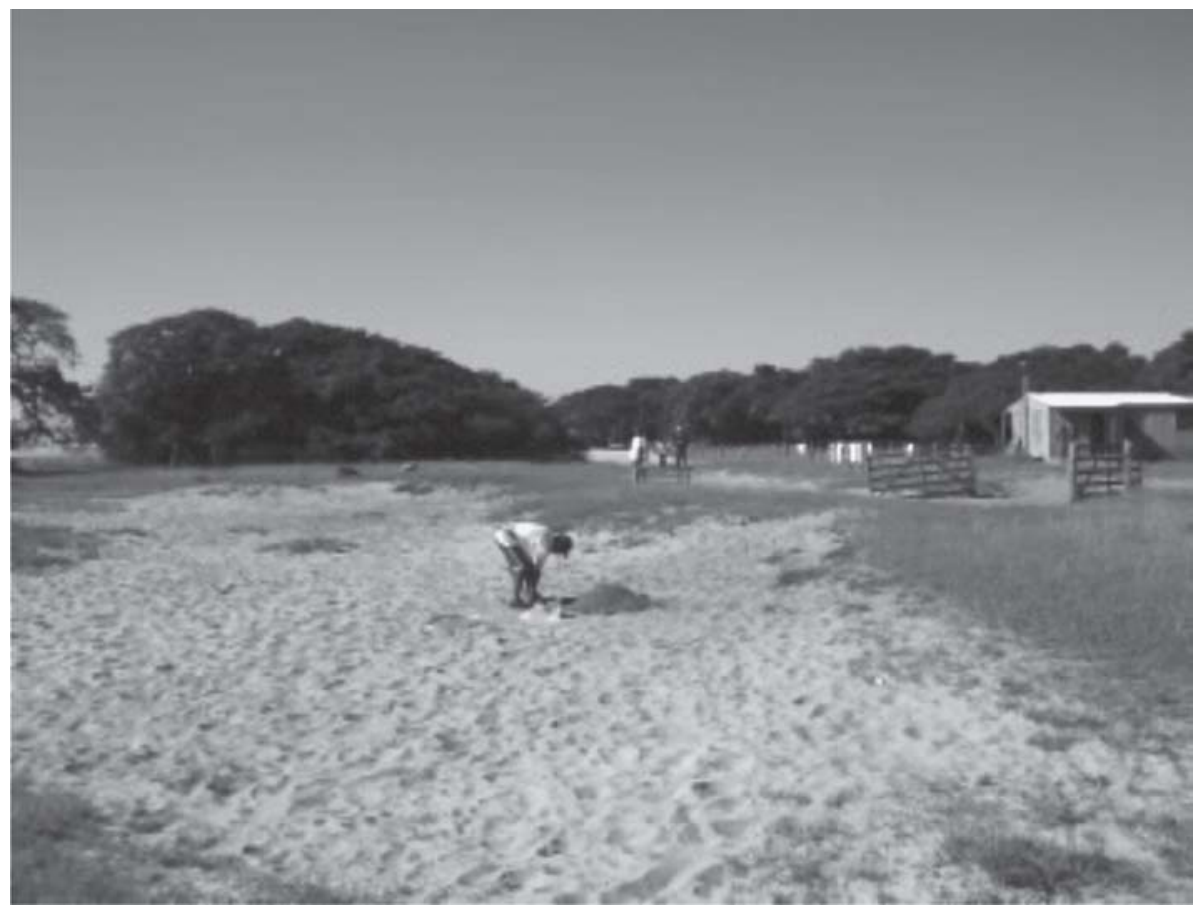

Fig. 2. Sondagens e coleta de superfície no sítio Sotéia. Notem-se ao fundo as margens da Laguna dos Patos.

ticas e assistemáticas realizadas durante duas campanhas arqueológicas, podendo-se definir duas áreas de concentração de cerâmica. Com isto, conseguimos perceber que se trata de um sítio multi-componencial, que primeiramente teve uma ocupação indígena Guarani, mas que em meados do século XVIII ou XIX se tornou uma área de ocupação histórica. ${ }^{6}$ A ocupação Guarani é indicada pelos materiais cerâmicos e líticos distribuídos numa área de aproximadamente 150 metros de raio, onde se destaca a ausência de estruturas arqueológicas em profundidade, a baixa diversidade de tipos cerâmicos e ausência de potes de grande porte. A partir desses dados podemos interpretar este sítio como um acampamento lacustre que se localiza às margens da Laguna dos Patos, em área de grande

(6) Referimo-nos aqui a um sobrado denominado de Sede da Fazenda Sotéia que se discute sobre a possibilidade de ter abrigado a Sede da Real Feitoria do Linhocãnhamo, ativa entre os anos de 1783 e 1789 (ver discussão em Cerqueira \& Loureiro 2004; Milheira 2008). abundância de camarão no período do verão, fato este constatado em entrevistas junto aos pescadores e que sugere que o sítio esteve direcionado, do ponto de vista estratégico, para a captação deste tipo de recurso lacustre (ver Milheira 2007b).

\section{PT-05-Lagoinha}

O sítio PT-05-Lagoinha foi identificado pelos trabalhos de levantamento arqueológico no ano de 2006, quando foi realizada apenas uma coleta de superfície assistemática. $O$ sítio se localiza na margem noroeste da ilha da Feitoria, a aproximadamente 150 metros da beira da Lagoa Pequena, abrangendo uma área de aproximadamente 20 metros de raio (ver na Fig. 3 o trabalho de sondagens no sítio Lagoinha). Foi realizado neste sítio um trabalho sistemático de coleta total de superfície e escavação de 21 sondagens em níveis artificiais de $10 \mathrm{~cm}$ e espaçados $10 \mathrm{~m}$ um do outro. Da mesma forma que o sítio Sotéia, as sondagens não evidencia- 
ram nenhum tipo de estrutura arqueológica em sub-superfície, sendo coletados apenas 57 fragmentos de paredes e 11 bordas, totalizando 68 fragmentos cerâmicos e três artefatos líticos (artefatos brutos de quartzo sem marcas de uso), sem a ocorrência de vestígios faunísticos. $\mathrm{O}$ conjunto cerâmico analisado demonstrou que todas as peças têm a superfície externa alisada. Ao projetar as vasilhas cerâmicas através das bordas foi possível identificar apenas três ñaetá e um cambuchí-caguâba. A medição do diâmetro de bordas da coleção (entre 12 e $20 \mathrm{~cm}$ de diâmetro) remete também a potes de pequenas dimensões, o que é complementado pelos índices de espessura predominantes que também se situam entre 8 e $10 \mathrm{~mm}$.

Pelos mesmos motivos do sítio Sotéia, a composição pouco variada de materiais e ausência de vestígios que indiquem uma ocupação permanente, interpreta-se este sítio como um acampamento que também pode estar relacionado à captação de recursos lacustres, visto que o mesmo se localiza na boca da Lagoa Pequena, local este de grande abundância de camarão e onde desovam diversas espécies de peixes no verão.

\section{PS-02-Camping}

O sítio Guarani PS-02-Camping se localiza na margem sudoeste da laguna a aproximadamente 100 metros da beira da praia. Seguindo o mesmo procedimento metodológico empregado nos demais sítios, procedemos à coleta de materiais de superfície e sondagens, escavadas em níveis de $10 \mathrm{~cm}$ de profundidade e $50 \mathrm{~cm}$ de lado, espaçadas em $10 \mathrm{~m}$ umas das outras. Desta forma foi possível realizar 42 poços testes que permitiram delimitar a área de dispersão dos materiais no sítio em 50 metros de raio. Nessa área foram definidas duas áreas de ocupação em que foram evidenciadas estruturas arqueológicas com funções distintas.

A primeira área foi definida como uma estrutura arqueológica de deposição de refugos, em que com as sondagens foi possível identificar um "pacote" de terra escura-preta formando uma lente côncava de não mais que $20 \mathrm{~cm}$ de espessura, onde a escavação evidenciou materiais faunísticos e fragmentos de cerâmica associados. O conjunto de materiais coletados é composto basicamente por fauna lacustre, que tratamos

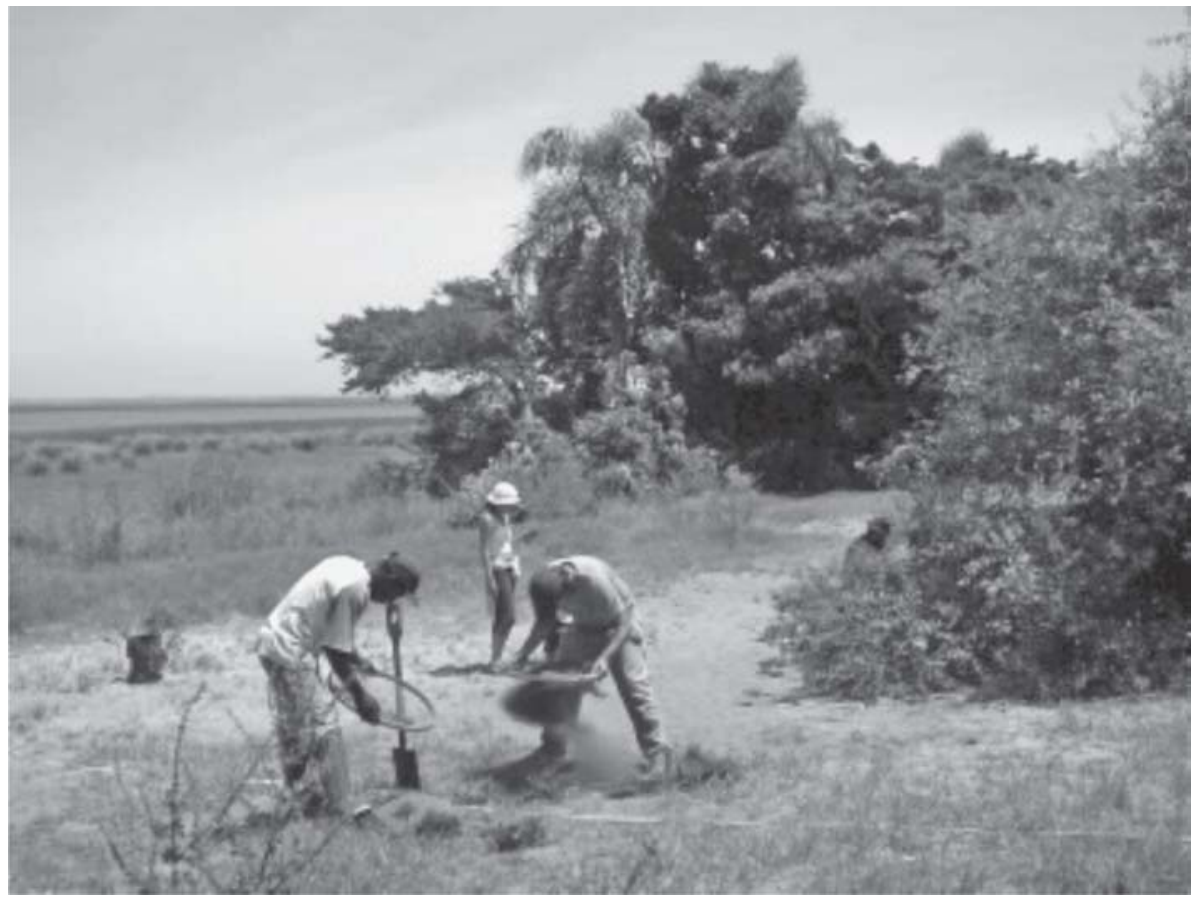

Fig. 3. Sondagens no sítio Lagoinha. Notem-se ao fundo as margens da Lagoa Pequena. 
aqui como vestígios de alimentação, dentre os quais foram identificadas peças carbonizadas e calcinadas, sendo mais um fator que reforça a idéia de deposição de refugos e posterior queima do mesmo (ver na Fig. 4 o perfil com a evidenciação da estrutura de deposição de refugos).

A segunda área de escavação foi definida pelo achado de um pote cerâmico enterrado. Nesse caso, ampliou-se a sondagem para uma área de escavação de $4 \mathrm{~m}^{2}$, com plotagem total das peças, em que se pôde evidenciar um pote articulado e semi-inteiro (ñaetá com decoração escovada).

No interior desta vasilha se encontravam dezenas de fragmentos de potes distintos, dando a impressão de que se trata de uma caçarola em que foi colocada uma porção de cerâmicas quebradas e posteriormente abandonada, ao redor da qual havia ainda dezenas de vestígios faunísticos associados. Este contexto foi datado através da técnica de AMS em $380 \pm 50$ AP, sendo a data calibrada colocada numa faixa temporal mais ampla, situada entre os anos 1450 a 1660 da Era Cristã ou 500 a 290 AP (Beta Laboratory Inc., $\mathrm{n}^{\circ}$ 234205). Do ponto de vista funcional, sugerimos que esse contexto possa ser considerado uma estrutura de fogueira, devido aos restos de alimentação e carvão em torno da caçarola, o que indica que possa ter havido preparo e consumo de alimentação (ver na Fig. 5 a escavação da estrutura de fogueira com a evidenciação da vasilha e vestígios associados).

A análise dos materiais cerâmicos indicou um predomínio de peças com superfície externa alisada (36,3\%), uma quantidade maior de peças com decoração plástica $(60,58 \%)$ e apenas $(3,12 \%)$ de peças com decoração cromática. As medições de espessura das paredes cerâmicas (predomínio entre 8 e $10 \mathrm{~mm}$ ), sugere se tratar de vasilhas de pequeno e médio porte, o que se complementa também pelas medições de diâme-
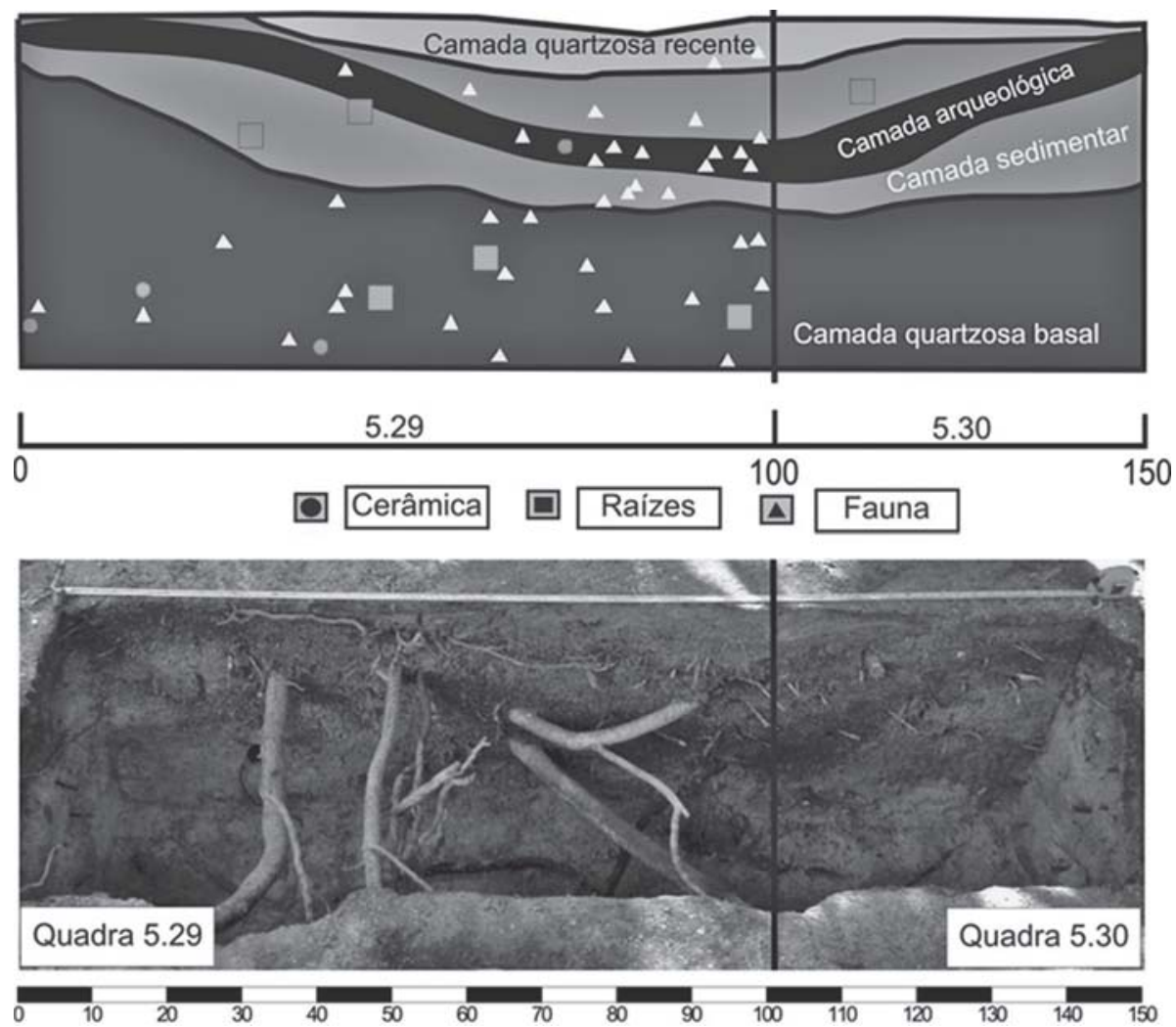

Fig. 4. Desenho de perfil estratigráfico e foto da escavação da estrutura de deposição de refugos (Perfil oeste, quadras 5.29 e 5.30, com 1.5 m de comprimento). Note-se a lente côncava de terra preta com vestígios arqueofaunísticos e cerâmicos associados. 
tro de bordas (entre 12 e 36 cm). A projeção gráfica dos potes a partir das bordas indica a ocorrência de uma vasilha do tipo ñaembé, duas vasilhas do tipo ñaetá, dois potes do tipo cambuchi-caguâba e três yapepó. No que se refere aos materiais líticos, foram identificadas apenas cinco peças, sendo todas lascas ou fragmentos de lascas de quartzo.

Embora este sítio tenha demonstrado maior densidade de materiais com relação aos sítios Sotéia e Lagoinha, tendo inclusive duas estruturas arqueológicas em profundidade (de deposição de lixo e de combustão), ainda assim a sua composição sugere se tratar de uma ocupação semi-permanente, sendo, neste caso, interpretado como um sítio acampamento de pequenas proporções.

\section{PS-03-Totó}

O sítio PS-03-Totó se localiza na praia do Totó, a aproximadamente $50 \mathrm{~m}$ da margem da Laguna dos Patos. Localizado na foz do arroio
Totó, o sítio é “cortado” por este pequeno arroio, de forma que são encontrados materiais arqueológicos na sua margem em pleno processo de impactação e, por vezes, deposição em contexto secundário (cf. Schiffer 1987). Seguindo o procedimento metodológico padrão da pesquisa, realizou-se o trabalho de coleta de superfície e prospecções através da escavação de 60 sondagens espaçadas em 20 metros ao longo do sítio, com ocorrência de vestígios em quase todas as sondagens a não mais que $20 \mathrm{~cm}$ de profundidade. Através deste procedimento foi possível compreender que se trata de um sítio com uma área de dispersão de materiais bastante ampla e que pode chegar até 200 metros de raio com uma densidade de materiais superior a todos os outros sítios identificados no litoral até o momento.

À beira do arroio Totó foi escavada uma estrutura funerária numa unidade de $2 \mathrm{~m}^{2}$, em que foi identificada uma urna funerária, (cambuchí guaçú) com decoração pintada em linhas vermelhas geométricas sobre engobo branco, além da ocorrência de fragmentos de,

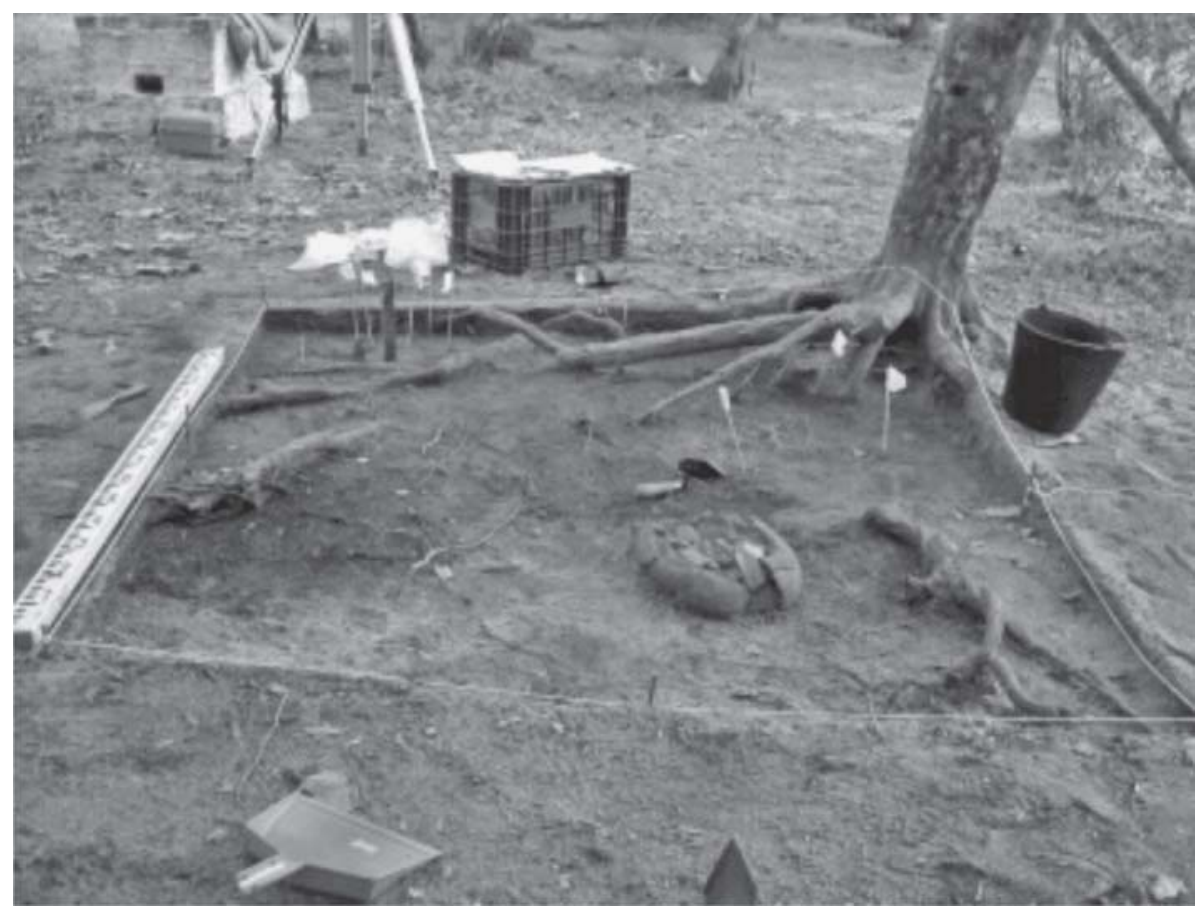

Fig. 5. Escavação da vasilha do tipo ñaetá associada a fragmentos de cerâmica e vestígios arqueofaunísticos. 
no mínimo, três potes diferentes que estavam associados (tigelas e caçarola). A urna estava bastante fragmentada pelas ações naturais e por isso não foi possível definir se os outros potes estavam em seu interior, emborcados ou ao redor da mesma, não sendo possivel também identificar restos humanos (ver na Fig. 6 a escavação da urna funerária e vestígios associados).

Numa outra área de intervenção foi escavada uma unidade de $4 \mathrm{~m}^{2}$, onde foram coletados ao todo 716 materiais cerâmicos, 139 materiais líticos, 172 vestígios arqueofaunísticos e 24 sementes de jerivá, além de grande quantidade de carvão que permitiu datar este contexto em $530 \pm 40 \mathrm{AP}$, com data calibrada entre os anos 1390 a 1440 da Era Cristã ou 560 a 510 AP (Beta Laboratory Inc. $n^{\circ}$ 237665). Esta estrutura se caracteriza então pela densa quantidade de vestígios arqueológicos dispostos numa

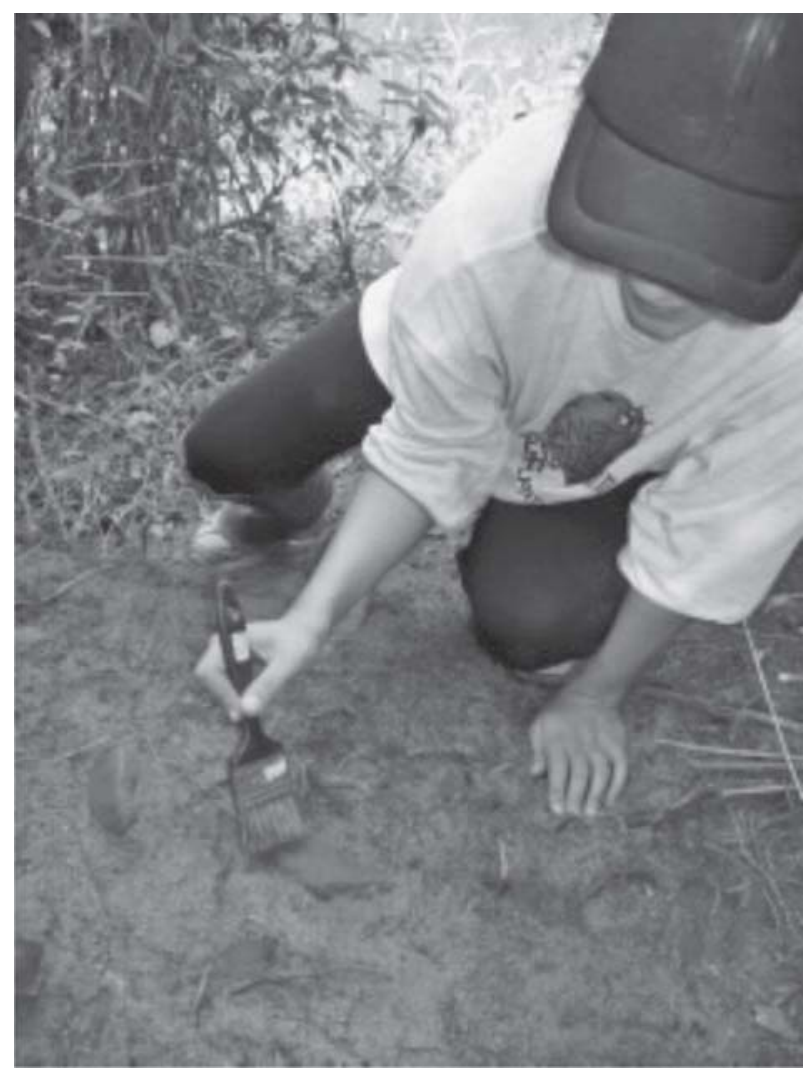

Fig. 6. Escavação da urna funerária associada a fragmentos de cerâmica de outros potes. Note-se o declive abrupto do terreno e o arroio Totó ao fundo. camada de terra preta antropogênica formada pela decomposição de matéria orgânica, que segue a topografia do terreno em declive na direção do arroio Totó, o qual, por sua vez, avança em direção à unidade de escavação encharcando a área e submergindo parte da estrutura (ver na Fig. 7 a escavação da estrutura arqueológica).

A três metros, no sentido leste, foi escavada uma trincheira de $10 \mathrm{~m}$ de comprimento por 0,50 $\mathrm{m}$ de lado e $1,5 \mathrm{~m}$ de profunidade, na qual foram coletados ao todo 335 materiais cerâmicos, 20 artefatos líticos e 45 vestígios arqueofaunísticos. Nesta trincheira foram evidenciados vários blocos de argila in natura que chamavam atenção por aparecerem em vários pontos da escavação. Inicialmente não conseguíamos inferir sobre a funcionalidade desses blocos de argila, se restos de produção de vasilhas cerâmicas ou talvez depositados no solo pela dinâmica do arroio Totó. Ao constatar a relação destes blocos de argila in natura com um esteio e estacas que parecem ter sido suportados pela argila, foi possível interpretar este contexto como uma unidade habitacional, em que os blocos de argila são vestígios de piso de chão batido (tudju) - muito comum entre os Mbyá Guarani (cf. Monticelli 1995) (ver imagens da trincheira e estruturas da unidade habitacional nas Figs. 8, 9 e 10).

A análise do material cerâmico demonstra uma preocupação estética e tecnológica maior que em todos os outros sítios do litoral. Das 829 peças analisadas $(40,77 \%)$ apresentam alisamento na superfície externa, enquanto um número surpreendente de $(49,07 \%)$ apresentam algum tipo de decoração plástica e $(14,81 \%)$ decoração cromática. Quanto às dimensões das vasilhas, as medições de diâmetros de borda (entre 12 e $50 \mathrm{~cm}$ ) indicam vasilhas de várias dimensões, desde miniaturas até grandes potes, como aquelas do tipo cambuchí guaçú. As medições das espessuras das paredes indicam também esta tendência, pois há um predomínio de peças com espessura 


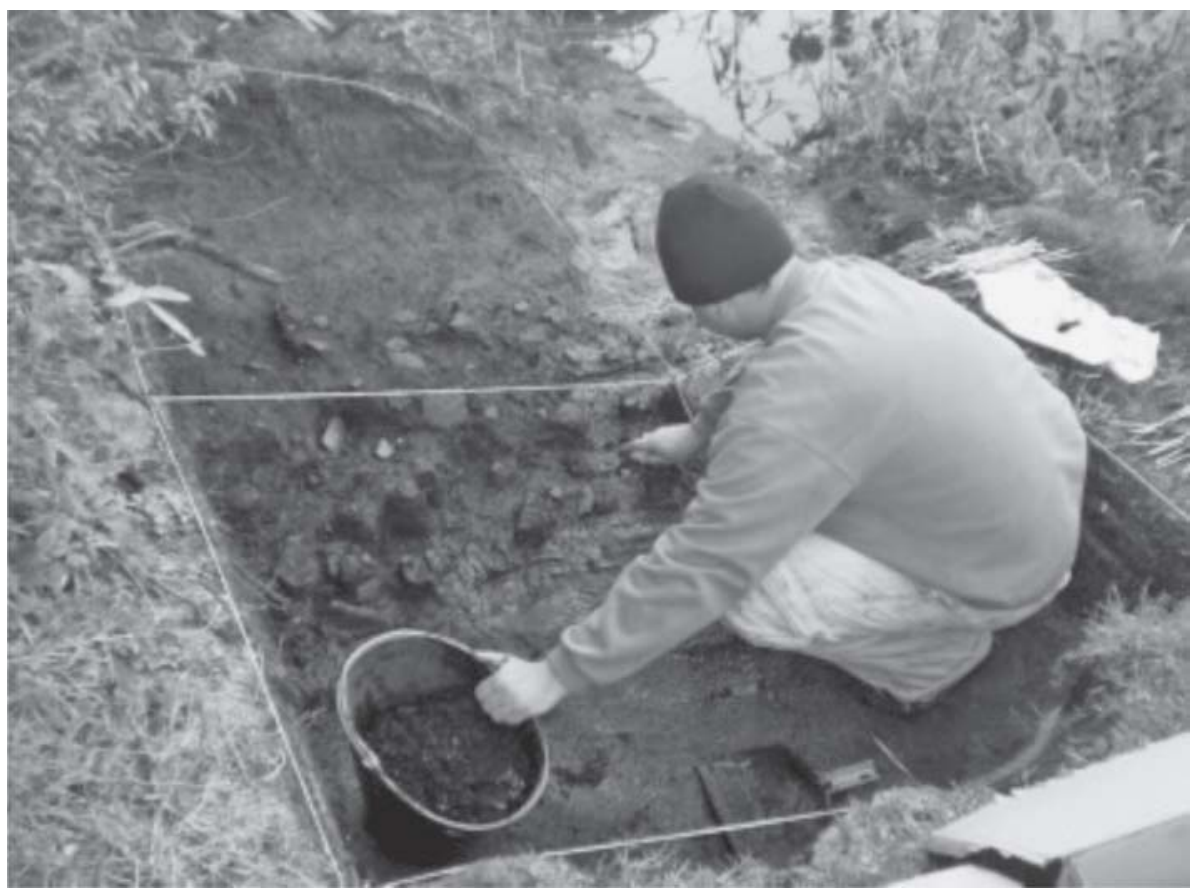

Fig. 7. Escavação da estrutura de terra preta referente à estrutura de deposição de refugos. Notese o grande acúmulo de artefatos arqueológicos à beira do arroio Totó.

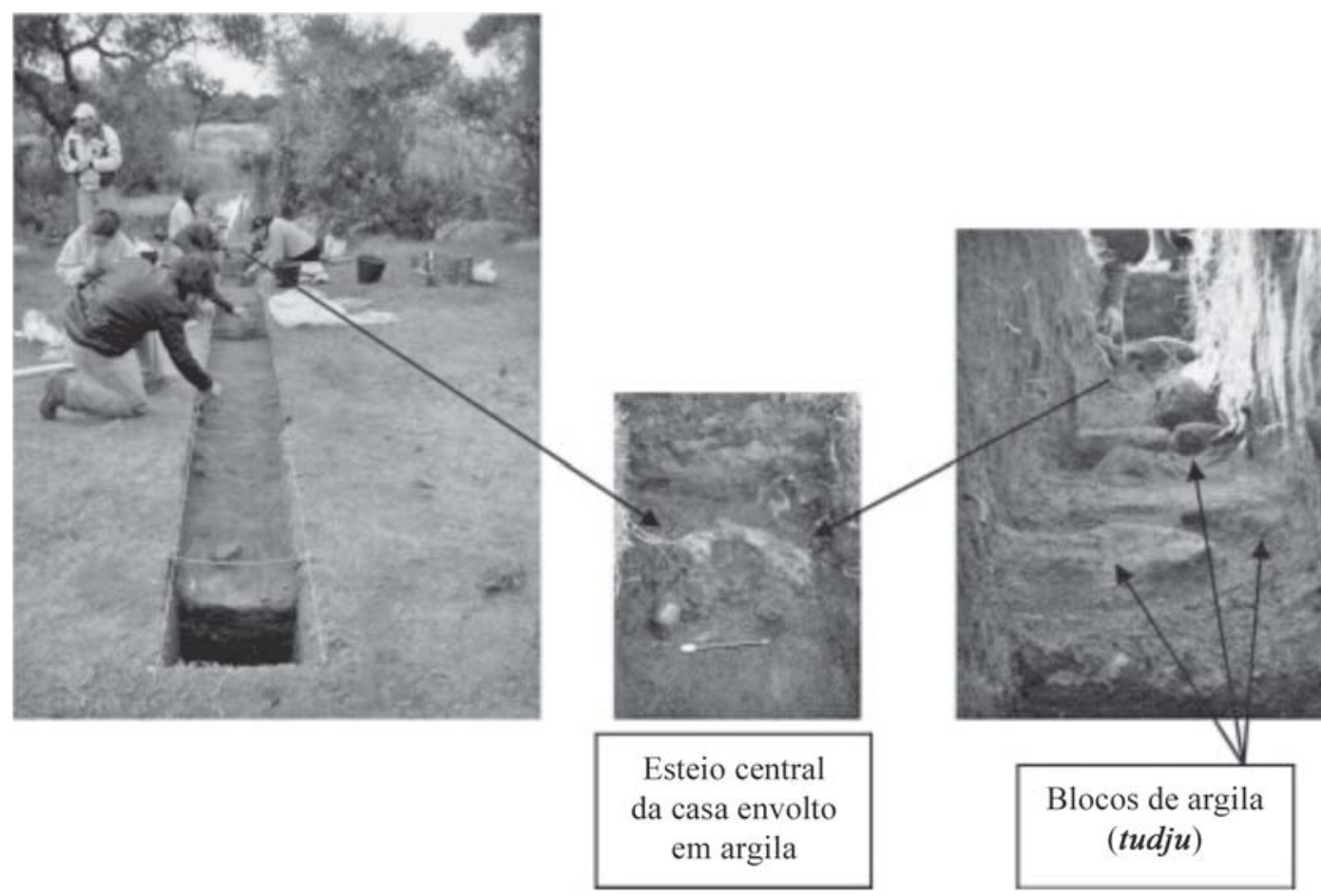

Figs. 8, 9, 10. Escavação da trincheira e evidenciação das estruturas da unidade habitacional caracterizadas por esteios, estacas e blocos de argila in natura. 
entre 10 e $12 \mathrm{~mm}$, mas nota-se um índice significativo de peças com espessuras acima de 14 $\mathrm{mm}$, remontando a potes de paredes grossas de grandes proporções, bem como índices abaixo de $6 \mathrm{~mm}$, indicando peças de paredes finas de pequenas dimensões. As projeções de potes a partir das bordas apontam para a presença de cinco vasilhas do tipo ñaembé, sete do tipo ñaetá, onze cambuchí caguâba e cinco como yapepó. Somente pudemos projetar a borda de um pote do tipo cambuchí guaçú, que apresenta um formato "exótico" em conjuntos de vasilhas Guarani, por apresentar na sua borda uma flange labial.

Com relação aos materiais líticos, temos no sítio Totó o conjunto mais interessante e complexo. Trata-se de um total de 139 artefatos líticos, (lascas e micro-lascas em calcedônia e arenito silicificado, afiadores em canaleta em arenito friável, lascas e materiais brutos em quartzo e dois fragmentos de lâmina de machado em basalto), materiais estes coletados, em sua maioria, na estrutura de deposição de lixo. A análise tecno-tipológica das peças apresentou duas questões a serem discutidas: 1 ) a matéria prima dos artefatos é inexistente nas imediações dos sítios, pois no litoral meridional da Laguna dos Patos não existem afloramentos de rocha por se tratar de uma formação sedimentar. Neste sentido, sugere-se que materiais tenham sido coletados através de exploração direta ou chegaram ao sítio por redes sociais de intercâmbio e comércio a distâncias de, no mínimo, 30 $\mathrm{km}$ (como no caso do quartzo e alguns tipos de basaltos) até $200 \mathrm{~km}$ (para o caso de arenitos, basalto e calcedônia) em direção às terras altas da serra do Sudeste e serra geral; 2) é importante também ressaltar que os materiais líticos analisados demonstraram bastante uso, sobretudo aqueles coletados na estrutura de terra preta. As lascas de calcedônia são bastante delgadas e há um grande percentual de fragmentos de lascas e estilhas, que indicam fabrico de implementos líticos no local. Além disso, os afiadores em canaleta parecem ter sido explorados até a exaustão, visto que têm diversos sulcos geralmente em todas as suas faces ativas. Neste sentido, o alto grau de exploração das peças e o padrão de descarte percebido são dados importantes para pensarmos sobre a funcionalidade da estrutura de terra preta do sítio, pois reforça que se trate de um local de deposição de refugos em que somente materiais sem condições de uso primário e restos de lascamento foram descartados.

Em suma, a unidade em que foi evidenciado o pacote de terra preta, com centenas de materiais arqueológicos, se configura como uma estrutura de deposição de lixo, a qual se encontra a três metros de distância da trincheira escavada, onde foram evidenciados vestígios que sugerem se tratar de uma unidade habitacional. Além disso, no mesmo sítio identificamos uma estrutura funerária a menos de $200 \mathrm{~m}$ desta área de habitação. Dada a grande densidade de vestígios identificados, estruturas arqueológicas bem definidas, áreas de atividade com funções específicas, diversos tipos de potes com forma e função variadas (grandes, médios e pequenos, com decorações e dimensões diversificadas) e materiais líticos produzidos com diversos tipos de matérias primas e que indicam uso diversificado, podemos entender este sítio como uma aldeia litorânea de ocupação permanente. Pensando numa relação sistêmica a partir dos dados acima, esta aldeia litorânea estaria relacionada aos demais sítios do litoral, se configurando como um assentamento central, com um adensamento populacional acentuado. Esta aldeia seria um ponto chave para o sistema de assentamento no que se refere à questão estratégica, pois podemos interpretar que sua presença no litoral, além de servir como ponto estratégico que visa ao abastecimento de recursos lacustres para o teko'á, é ainda um ponto de manutenção da dominação territorial do litoral da Laguna dos Patos.

\section{Sítios da Serra}

A Serra do Sudeste, conhecida regionalmente como Serra dos Tapes, corresponde ao Escudo Rio-grandense (Escudo Cristalino PréCambriano) e se caracteriza por ser uma área elevada e ondulada, com vales encaixados com altitudes médias entre 100 m e 300 m (Rosa 1985). A paisagem se caracteriza como uma área com cobertura vegetal da Floresta Estacional 
Semi-Decidual e por rios e córregos que fluem em direção à laguna dos Patos (Radam Brasil 1986; Rosa 1985; Rogge 2004).

Na Serra do Sudeste os sítios demonstraram um padrão de assentamento semelhante, pois são localizados em topo/meia encosta de morro, próximos do morro dos Três Cerros que é o maior acidente geográfico, sendo um marco na paisagem local. Esses sítios todos se encontram em terras que são aradas há mais de 70 anos em média, comprovando a potencialidade produtiva das terras, mas que, por outro lado, gerou vários problemas para preservação do registro arqueológico. Para a análise espacial dos sítios da serra nos utilizamos apenas daqueles dez sítios localizados no vale do arroio Andrade que formam um cluster. Esta escolha se deu em função de que nesta área o trabalho de levantamento foi realizado de forma sistemática, se comparado a outra área levantada na serra.

\section{Sítio PSGPA-01-Raffi 1}

No sítio Raffi 1 escavamos uma série de sondagens em área de mata densa secundária e em terreno arado, assim como realizamos coletas de superfície geo-referenciada nesses mesmos locais. As sondagens não evidenciaram nenhum tipo de estrutura arqueológica, mesmo nos locais onde o Sr. Raffi indicou como pontos onde antigamente se encontrava terra preta com muito carvão ou grandes concentrações de cerâmica e materiais líticos. Somente as coletas de superfície deram resultado no que se refere ao registro de vestígios arqueológicos.

Foram coletadas 215 peças através de coleta de superfície e sondagens (195 são paredes cerâmicas e 20 são bordas) em que a análise do conjunto cerâmico identificou um predomínio de peças com algum tipo de decoração plástica (42,78\%), um menor índice de peças com decoração cromática $(9,32 \%)$ e um índice também elevado de peças com superfície externa alisada (47,90\%). Essa coleta superficial permitiu não só identificar vestígios, mas também definir através da dispersão dos materiais no solo a dimensão espacial do sítio, cuja área ultrapassa 400 metros de diâmetro. A projeção de vasilhas no sítio Raffi foi realizada através de oito bordas cerâmicas, sendo três vasilhas projetadas como do tipo ñaetá, três como cambuchí caguâba, uma como yapepó e uma borda que remonta a uma vasilha do tipo cambuchí com um formato "exótico", por apresentar também uma borda com flange labial. A cerâmica analisada sugere também que tenhamos um conjunto formado por potes de médias e grandes proporções. Há um predomínio de fragmentos com espessuras entre 10 e $12 \mathrm{~mm}$, surgindo um índice importante nas espessuras acima de $14 \mathrm{~mm}$. Complementam esses dados as dimensões de diâmetro de borda, que indicam a ocorrência de potes de dimensões médias e grandes.

\section{Sítio PSGPA-02-Schwanke 1}

No sítio Schwanke 1 não foram realizadas sondagens ou medições topográficas. Logo, não foi possível identificar qualquer tipo de estrutura sub-superficial. Somente coletas de superfície georeferenciada foram realizadas, através das quais, coletamos 197 peças cerâmicas no assentamento, entre as quais 182 são paredes e 15 são bordas. Destas peças analisadas 48,20\% têm decoração plástica, 37,05\% têm alisamento externo e apenas $14,75 \%$ apresentam decoração cromática. Além disso, as projeções de vasilhas permitiram definir três vasilhas como do tipo ñaetá, duas como yapepó e uma como ñaembé. As medições de diâmetro de borda sugerem potes de proporções medianas e grandes (dimensões entre 20 e $56 \mathrm{~cm}$ ) o que é reforçado pelo predomínio de paredes com 10 a $12 \mathrm{~mm}$ até paredes com 22 $\mathrm{mm}$. Chama atenção no sítio, além das peças cerâmicas identificadas, uma estrutura de terra preta de formato circular com um diâmetro de aproximadamente $10 \mathrm{~m}$, que pudemos caracterizar como um fundo de cabana (cf. Pallestrini \& Morais 1984; Noelli 1993; Assis 1996; Soares 1997, 2005; Carle 2002).

\section{Sítio PSGPA-03-Rutz}

No sítio Rutz também não foram realizadas sondagens nem medições topográficas e não foi 
possível identificar qualquer tipo de estrutura arqueológica. Procedemos apenas à coleta de superfície geo-referenciada, totalizando apenas 69 fragmentos cerâmicos (62 paredes e sete são bordas). Das peças analisadas $(49,27 \%)$ têm a superfície externa alisada, $(44,90 \%)$ apresentam decoração plástica e apenas $(7,22 \%)$ com decoração cromática. As projeções de bordas indicaram a presença de vasilhas de proporções medianas (20 a 28 cm de diâmetro de borda), das quais duas são vasilhas do tipo ñaembé e apenas uma do tipo yapepó. Nota-se, neste sítio, que houve uma impactação bastante acentuada que fez com que as peças identificadas ficassem bastante erodidas e fragmentadas, visto que não se encontram fragmentos grandes de cerâmica, somente pequenos cacos. Esses materiais estão dispersos num diâmetro de aproximadamente 300 metros.

\section{Sítio PSGPA-04-Ribes}

No sítio Ribes, em uma primeira visita constatamos a sua potencialidade de pesquisa porque há décadas atrás o proprietário coletou uma urna funerária, deixando apenas o "buraco" onde a mesma se encontrava. Além disso, através das sondagens e coleta de superfície foi possível identificar três manchas de terra preta que são interpretadas como estruturas habitacionais, as quais, por sua vez, foram muito impactadas pela agricultura permanente e pelas tradicionais técnicas de coivara para desmatamento.

Foram realizadas sondagens com escavadeira manual, eqüidistantes em $20 \mathrm{~m}$, cobrindo uma área de $140 \mathrm{~m}$ x $80 \mathrm{~m}$ da totalidade do terreno, onde se localiza o sítio arqueológico. Com isto, pudemos definir que a área de dispersão dos materiais sobre o sítio arqueológico se dá num raio de $250 \mathrm{~m}$. Além das sondagens com escavadeira, realizamos sondagens no interior das manchas de terra preta, permitindo definir que uma delas tem $10 \mathrm{~m}$ de diâmetro; a outra $20 \mathrm{~m}$ de diâmetro e a última $18 \mathrm{~m}$ de diâmetro. Foram coletados e analisados 150 fragmentos cerâmicos, sendo 133 paredes e 17 bordas, dos quais, a sua grande maioria se encontrava no interior da mancha preta de maior porte, demonstrando relação direta entre as unidades de habitação e o descarte dos materiais. As projeções de vasilhas através das bordas indicaram a presença de três vasilhas cerâmicas, sendo um yapepó, um cambuchí caguâba e um naetá, com dimensões de diâmetro de borda entre 22 e $30 \mathrm{~cm}$. A análise tecno-tipológica das peças indicou a presença de $(42,66 \%)$ de fragmentos com a superfície externa alisada, $(54,63 \%) \mathrm{com}$ decoração plástica e apenas $(1,33 \%) \mathrm{com}$ decoração cromática.

Para averiguar possíveis materiais no contexto da urna funerária retirada pelos agricultores há décadas atrás, escavamos o entorno da cova funerária onde se localizava a mesma. Abrimos então uma área de escavação que chegou a $15 \mathrm{~m}^{2}$, sendo este espaço escavado através da técnica de decapagem. Desta forma, foi possivel compreender que se trata de uma estrutura funerária com a ocorrência de duas urnas funerárias dispostas lado a lado. A urna funerária escavada é uma vasilha do tipo cambuchí guaçú que teve sua borda quebrada por ações naturais. Estava depositada em sentido vertical, com um pote do tipo cambuchí guaçú emborcado como tampa, que foi retirado inteiro. Em seu interior não foi identificado qualquer tipo de vestígio de esqueleto humano nem mesmo carvão que pudesse gerar uma amostra para datação, logo, a única possibilidade de datação foi através da técnica de Termoluminescência, apontando a idade de 510 \pm 70 A.P. ou o ano de 1440 da Era Cristã (protocolo 1968 do LVD-FATEC) (ver na Fig.11 a escavação da urna funerária 12 e na Fig. 12 o detalhe da secção superior da vasilha).

O jogo comparativo: em busca de padrões, semelhanças e diferenças

A partir dos dados apresentados ao longo deste trabalho é possível iniciar uma discussão que busca a constituição de um modelo interpretativo baseado na perspectiva sistêmica (Binford 1980; Shapiro 1984; Dias 2003). Trabalhamos com o pressuposto de que haja um contexto sistêmico macro-espacial que articularia os sítios arqueológicos enquanto espaços de ocupação com funções específicas e dispostos estrategicamente 


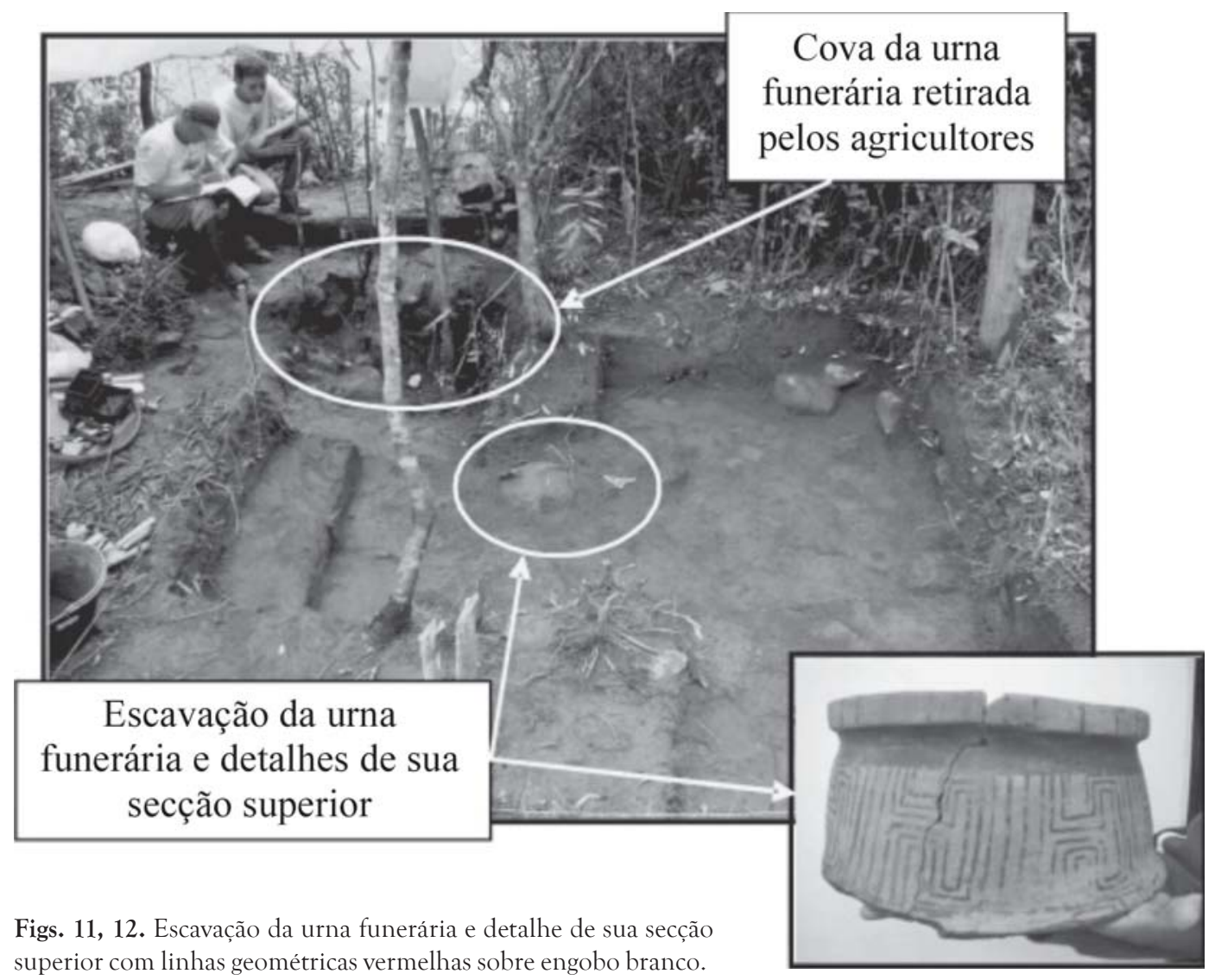
superior com linhas geométricas vermelhas sobre engobo branco.

na paisagem. Neste sentido optamos por interpretações que se pautam por uma relação intra e inter sítio, na qual o contexto macroespacial pode ser considerado uma área de domínio territorial dos grupos Guarani denominada teko'á, que consiste no espaço onde as práticas sociais em nível regional se desenvolvem através de seus desdobramentos políticos, religiosos, culturais, ambientais e econômicos.

A organização territorial Guarani se dá através de diferentes dimensões espaciais, desde a casa (oka), onde reside a família nuclear, até o guará o território Guarani, no seu nível mais amplo. Vários limites sócio-políticos são conhecidos na organização social dos grupos Guarani que formam o cacicado e suas áreas de abrangência: a família nuclear, a família extensa ou teýy, a aldeia ou amundá, o conjunto de aldeias inseridas em um território ou teko’á e o conjunto de teko'á que forma um território amplo, como uma nação, guará (Noelli 1993; Assis
1996; Soares 1997). Por definição, o teko’á se constitui como o conjunto de aldeias e acampamentos que formam então um território de domínio e influência, limitado por acidentes geográficos como rios, morros, arroios etc.. Esses limites, além de serem definidos pelos aspectos simbólico-religiosos são também estabelecidos através das alianças políticas que determinam graus de prestígio e status social nas relações entre aldeias (Noelli 1993; Soares 1997, 1999). O teko’á pode atingir, segundo Noelli (1993), um raio de $50 \mathrm{~km}$, abrangendo neste espaço vários tipos de ambientes, cujas características físicas e os pontos estratégicos para exploração de seus recursos são mapeados cognitivamente pelos grupos, constituindo as partes do território. O teko'á é constituído por eco-zonas ou diferentes esferas de convívio e atuação cultural, integrando aldeias e sítios para acampamentos de pesca, caça e coleta, assim como as roças e os caminhos entre esses espaços. Conforme Meliá 
(1987, apud Noelli 1993) existem três raios de ação dos grupos indígenas dentro do teko'á: a vegetação circundante, a roça e a aldeia.

Além dos macro-espaços que constituem o território Guarani, são conhecidas áreas de funcionalidade específica, voltadas para a exploração de recursos, referenciadas pela literatura arqueológica como micro-ambientes ou ecozonas. Aí se desenvolvia a captação dos recursos ambientais e a produção de bens materiais. Nesses assentamentos voltados à caça, pesca, roça e coleta, denominados de acampamentos (Novaes 1983; Noelli 1993; Assis 1996), os grupos indígenas construíam abrigos utilizados pelo tempo necessário à execução de cada atividade. Denominados pelos Guarani como tapýi (Novaes 1983; Assis 1996), estes acampamentos se localizavam geralmente às margens dos rios, córregos e lagoas, elementos da maior importância para a economia Guarani. Durante todo ano ou em períodos sazonais, grupos de pessoas de uma ou mais aldeias deslocavam-se de suas residências e acampavam às margens dessas áreas de assentamento para exploração desses recursos. Nos acampamentos construíam estruturas necessárias ao convívio quotidiano e utilizavam instrumentos para o abate, manipulação, armazenamento e transporte dos alimentos. Os tapýi eram bastante simples do ponto de vista arquitetônico e geralmente tinham estruturas auxiliares para o controle dos recursos na paisagem, para coleta de moluscos e manipulação de alimentos. Suas estruturas composicionais simples deixavam poucos vestígios, o que se dava também porque o objetivo estratégico de ocupação do acampamento era o de abastecer a aldeia principal, gerando poucos vestígios materiais no solo.

Trazendo os dados apresentados para a discussão sistêmica do conjunto de sítios Guarani da área de estudo, podemos inferir que os mesmos sejam elementos de um teko'á que se articula entre a região litorânea e serrana. $\mathrm{O}$ teko'á do arroio Pelotas, como denominamos o território de domínio estudado, abrangeria então uma área de pelo menos $35 \mathrm{~km}$ de raio, havendo duas porções: litoral e serra, que se diferenciam não somente pelas características ambientais, mas também pelo tipo de assenta- mento e estratégia de dominação territorial. Para entendermos o contexto de ocupação e o domínio territorial numa perspectiva sistêmica é necessária a caracterização de cada porção do teko’á.

\section{A porção litorânea do teko’á do arroio Pelotas}

Para a caracterização da porção litorânea do teko'á do arroio Pelotas é importante delinearmos alguns aspectos que evidenciam a similaridade nas formas do assentamento, buscando-se elementos para o entendimento de um padrão de assentamento litorâneo, embora existam diferenças funcionais dos sítios. Esta interpretação se dá em virtude de diversos fatores: a) os sítios se localizam próximos à laguna, em áreas elevadiças como paleo-dunas e pequenas elevações no terreno; b) no que se refere ao terreno, as terras litorâneas são de fraco potencial para o cultivo agrícola de algumas espécies porque a planície costeira se caracteriza por ser arenosa e muito recente, fatores estes que limitam a capacidade produtiva local (RadamBrasil 1986); c) os sítios se situam em áreas de ecótono ambiental, o que garante o abastecimento relativo a uma dieta alimentar equilibrada de animais, peixes, aves, répteis e mamíferos que circulam por estas áreas, além de uma série de tipos de frutos, raízes para alimentação e árvores e juncais para construção de estruturas arquitetônicas e cestaria; d) quanto à distribuição dos sítios na paisagem, ao analisar o mapa de distribuição dos sítios Guarani fica evidente a alta dispersão dos mesmos ao longo da faixa litorânea, com distâncias entre 2 e 3 km entre si.

Em linhas gerais percebemos algumas características similares que configuram um padrão de assentamento Guarani no litoral. No entanto, para entendermos a correlação sistêmica entre os sítios é necessário compreender as particularidades de cada tipo de assentamento: aldeia e acampamento. Estes dois tipos de assentamentos, além de terem funções diferenciadas têm também características físicas e composicionais também distintas, resultantes das atividades culturais a que se destinaram. Como visto acima, 
através da análise e sistematização dos dados é possivel pensar que, do ponto de vista funcional, os sítios Sotéia e Lagoinha na Ilha da Feitoria e o sítio Camping na margem sudoeste da Laguna podem ser interpretados como sítios acampamento que tiveram uma ocupação rápida ou semi-permanente, voltada para a pesca e/ou coleta de recursos lacustres. Por outro lado, o sítio Totó foi considerado uma aldeia litorânea, ocupado para moradia permanente. Este panorama interpretativo surge a partir de um esquema comparativo relativo aos aspectos composicionais dos sítios acampamento e aldeia:

A) Os sítios acampamento têm uma densidade e dispersão de materiais arqueológicos bastante baixas se comparadas à aldeia. A aldeia do Totó, por exemplo, tem uma densidade de materiais pelo menos 7,5 vezes maior que o sítio acampamento Camping, o segundo em índice de densidade no litoral. Além disso, a dispersão dos materiais arqueológicos nos sítios acampamento não ultrapassa o diâmetro de 200 m, enquanto a aldeia do Totó parece ter uma distribuição de materiais que pode chegar a um diâmetro de $400 \mathrm{~m}$, demonstrando se tratar de um assentamento densamente ocupado e disperso pelo terreno.

B) As coletas de superfície e as sondagens demonstraram claramente que os sítios acampamento se caracterizam por serem de ocorrência predominantemente superficial, pois não foram identificadas estruturas sub-superficiais ou camadas arqueológicas indicadoras de ocupação mais densa. Somente foram identificadas estruturas arqueológicas no caso do sítio PS-02Camping, mas que, a priori, não parecem indicar um contexto denso de ocupação. Por outro lado, na aldeia do Totó foram identificadas uma estrutura funerária, uma estrutura de deposição de lixo e uma estrutura arquitetônica, inclusive com esteio, estacas e blocos de argila in natura, contexto que sugere se tratar de um piso de habitação com suas respectivas estruturas arquitetônicas de sustentação da residência, indicando, neste caso, se tratar de um espaço mais permanentemente ocupado se comparado aos demais sítios litorâneos.
C) A análise dos conjuntos cerâmicos dos sítios acampamento demonstrou que há um predomínio de peças com espessuras entre 8 e 10 $\mathrm{mm}$ que remontam a potes pequenos e médios. Essa constatação é reforçada se conjugada com os valores de diâmetros de bordas que indicam que os potes cerâmicos também são de pequeno e médio porte. No sítio Totó, por sua vez, o índice de espessura também tem predomínio entre 8 e $10 \mathrm{~mm}$, mas há uma variação significativa desses índices, surgindo peças mais finas e mais grossas. Da mesma forma, as projeções de potes e os valores de diâmetro de bordas indicam que o conjunto artefatual do sítio Totó é muito variado, havendo grande quantidade de vasilhas de pequeno, médio e grande porte.

D) Os potes cerâmicos dos sítios acampamento são representativos de classes eminentemente funcionais ou utilitárias, utilizadas no quotidiano para preparação de alimento, como as panelas e caçarolas (yapepó e ñaetá), tigelas para beber (cambuchí-caguâba) e pratos para comer (ñaembé) (La Salvia \& Brochado 1989). Os potes utilizados para produção de bebidas alcoólicas fermentadas, para rituais funerários e/ ou armazenamento de água conhecidos como cambuchí guaçú (talhas) não foram encontrados nestes sítios acampamento. Este é um dado importante, já que se pode considerar que as talhas são indicadores de permanência, pois são potes que não são normalmente transportados, sendo encontrados mais freqüentemente em aldeias (Shapiro 1984; Rogge 1997; Soares 1997). Além disso, a análise dos aspectos formais e tecno-tipológicos indica um predomínio de fragmentos de vasilhas sem decoração plástica ou cromática, com acabamento superficial bastante simples, sem nenhum tipo de sofisticação tecnológica aparente, indicando também se tratar de vasilhas funcionais de uso quotidiano (La Salvia \& Brochado 1989).

Por outro lado, o registro material da aldeia do Totó permitiu a identificação de, no mínimo, duas vasilhas do tipo cambuchí guaçú (uma como urna funerária e a outra na estrutura de deposição de lixo). É importante destacar também que além das talhas foi registrado um conjunto muito variado de vasilhas cerâmicas, 
em que foram identificados potes de todos os tipos, tanto aqueles utilizados para atividades funcionais quotidianas, como aqueles para fins ritualísticos, produção de bebidas e armazenamento de água. No que se refere ao acabamento das vasilhas, o conjunto cerâmico da aldeia do Totó também indicou uma variação muito importante, em que muitas peças apresentam decorações plásticas e cromáticas, brunidura, polimento, indicando se tratar de um conjunto artefatual tecnologicamente mais sofisticado no que se refere ao estilo das vasilhas.

E) Outra questão importante diz respeito aos materiais líticos. A análise deste tipo de material proveniente dos sítios acampamento permite interpretar que estejamos lidando com uma indústria expediente, em que o investimento em obtenção de matéria prima não foi muito acentuado, seguindo-se a um baixo investimento na manufatura dos instrumentos, visto que predominam poucas lascas e blocos de quartzo. No sítio Totó, por sua vez, a análise dos materiais líticos sugere que se trata de uma indústria de curadoria, já que houve um investimento bastante significativo em obtenção de matéria prima (dadas as grandes distâncias das fontes), assim como se percebe que a atividades de manufatura de artefatos líticos foi realizada em vias de otimização no uso destas matérias primas. O conjunto lítico, além de ter variabilidade em suporte (blocos, plaquetas e seixos) e matéria prima (arenito friável, arenito silicificado, calcedônia, quartzo, basalto e granito) é também muito mais variado (se comparado aos sítiosacampamento) nos seus aspectos tipológicos e quantitativos, pois se identificaram diferentes tipos de lascas em variados suportes, afiadores em canaleta, fragmentos de lâminas de machado e blocos e seixos de quartzo (Binford 1979; Noelli 1993). ${ }^{?}$

Seguindo esses critérios comparativos apresentados acima, correlacionados ao padrão de assentamento, pode-se pensar em um sistema

(7) Ver Milheira (2008: 82-90) para mais detalhes sobre os procedimentos de análise e aprofundamento dos resultados que nos levaram a estas interpretações. de assentamento Guarani litorâneo completamente integrado e sincrônico, em que os sítios acampamento, localizados em pontos estratégicos do território de domínio, permitem otimizar a captação de recursos para então abastecer a aldeia central. É importante lembrar que os sítios acampamento estão localizados em áreas em que os recursos lacustres, como camarão, siris e peixes, até hoje são pescados em maior abundância, são, neste caso, "pesqueiros", mapeados cognitivamente como pontos integrantes do território de domínio, onde é possível explorar os recursos com maior sucesso. Esse é o caso da Ilha da Feitoria, onde se localizam os sítios Sotéia e Lagoinha, em que dezenas de pescadores hoje ocupam a margem leste para pescar camarão e siri sazonalmente entre os meses de fevereiro e abril (Milheira 2007b). Da mesma forma, no Pontal da Barra, entrada do canal São Gonçalo onde se localiza o sítio Las Acácias, diversas espécies migram para a Lagoa Mirim no verão, sendo um local de pesca abundante.

A aldeia do Totó localiza-se num ponto da costa de onde é possível visualizar todos os outros sítios litorâneos. Este fator permite pensar que a aldeia tenha sido posicionada estrategicamente numa área central, possivelmente para controle territorial e maior facilidade com relação à mobilidade e logística para atividades de exploração ambiental e econômica. A aldeia, nesse caso, é o ponto central, para onde as atividades são voltadas e pode ser interpretado como o local de ocupação aglutinante e de convergência, já que é de onde os grupos se deslocam para atividades específicas nas ecozonas e acampamentos anexos e voltam ao fim das atividades. A aldeia é o espaço da vida coletiva, da socialização, onde as tradições Guarani se estruturam e reestruturam a partir do compartilhamento de idéias e de visões de mundo através de gerações.

\section{A porção serrana do teko’á do arroio Pelotas}

Um primeiro ponto a ser destacado na caracterização da porção serrana do teko'á do arroio Pelotas diz respeito ao padrão de assentamento. Tratamos aqui apenas dos dez 
sítios arqueológicos Guarani que foram identificados na Serra do sudeste, entre o vale do arroio Andrade e arroio Correntes, os quais apresentam as seguintes características: a) os sítios localizados na serra se situam todos em topo/meia encosta de morro íngremes, em alturas que variam de $109 \mathrm{~m}$ até $288 \mathrm{~m}$, distando não mais de $500 \mathrm{~m}$ das vertentes do arroio Andrade ou de vertentes do arroio Correntes; b) todos os sítios identificados se localizam em meio à floresta densa, classificada como Semi-Decidual (Radam Brasil 1986). O terreno onde se distribui este tipo de floresta tem bastante potencial produtivo, permitindo o cultivo de inúmeras espécies agrícolas, o que se nota pela tradicional produção agrícola até hoje; c) no que se refere aos recursos orgânicos também há uma grande quantidade de espécies de fauna e flora disponíveis ao longo dos vales e matas densas. Embora não tenhamos registrado materiais arqueofaunísticos nos sítios, não fica difícil supor que o ambiente da serra disponibilizasse um conjunto faunístico e uma fitoecologia com alto potencial econômico; d) diferentemente dos sítios litorâneos, os sítios da serra se apresentam bastante próximos uns dos outros, formando clusters na paisagem ou, em outras palavras, um aglomerado de assentamentos que indicam se tratar de um terreno densamente e tradicionalmente ocupado; e) quanto à função dos sítios localizados na serra, todos eles parecem ser aldeias com uma grande distribuição de materiais arqueológicos, sugerindo um alto índice de densidade de materiais. Para esta interpretação devemos levar em consideração as análises dos vestígios materiais cerâmicos, que indicam, sobretudo, a presença de potes de médio e grande porte, com espessuras predominantes entre 10 e $12 \mathrm{~mm}$, surgindo uma freqüência significativa de espessuras acima de $14 \mathrm{~mm}$. Trata-se de cerâmicas em que o índice de decoração plástica e pinturas é bastante elevado, além de polimento e brunidura terem sido identificados nos conjuntos analisados. Além disso, é importante relembrar que é comum serem identificadas manchas de terra preta na superfície do solo, que sugerem se tratar de vestígios de habitação.

\section{Constituindo um modelo: a composição de uma (pré) história Guarani na região}

Ao caracterizar as duas porções do teko'á do arroio Pelotas podemos então refletir sobre suas relações sistêmicas. Sugere-se que o principal indicador da relação entre os sítios da serra e do litoral é o material lítico identificado nos sítios litorâneos, cujas matérias primas indicam que pode haver uma relação entre os dois ambientes e áreas de ocupação em questão. Nos sítios localizados na Ilha da Feitoria foram coletados instrumentos líticos simples, do ponto de vista tecnológico, os quais foram confeccionados predominantemente em quartzo, quando não são apenas blocos destas matérias primas sem marcas de uso. $\mathrm{O}$ mesmo padrão se dá no sítio Camping, havendo uma maior quantidade e densidade de vestígios líticos apenas na aldeia do Totó, onde foram encontrados materiais líticos confeccionados em calcedônia, basalto, arenito friável e silicificado, granito e quartzo. $\mathrm{O}$ indicativo da relação litoral/serra nesse caso é a ausência de fontes destas matérias primas na margem da Laguna dos Patos. Da mesma forma não são conhecidas cascalheiras nos córregos e arroios que deságuam na Laguna, muito menos afloramentos rochosos que permitissem a exploração em blocos. As fontes das matérias prima utilizadas pelos Guarani do litoral somente são encontradas a partir da região do Escudo Sul-riograndense $(40 \mathrm{~km})$ ou mais além, na Depressão Periférica $(130 \mathrm{~km})$ e Planato da Serra Geral (200 km).

Sendo assim, pode-se inferir que os grupos Guarani que ocuparam a costa litorânea exploravam diretamente as terras altas para captação de recursos líticos, assim como deveriam manter redes de trocas de bens materiais com os grupos além da serra. Neste sentido, podemos pensar que o teko'á, ou o domínio territorial Guarani em nível regional, poderia abranger a região litorânea e serrana, atingindo assim ambientes distintos numa área ampla que abrange mais de $35 \mathrm{~km}$ de raio, ademais, a manutenção de redes de troca de bens materiais com outros grupos poderia se dar em distâncias de até 200 km, num raio de ação que se estende além do teko'á, alcançando a esfera do guará (ver na Fig. 13 o mapa com localização dos sítios arqueológicos da serra e litoral, demonstrando o contexto regional). 


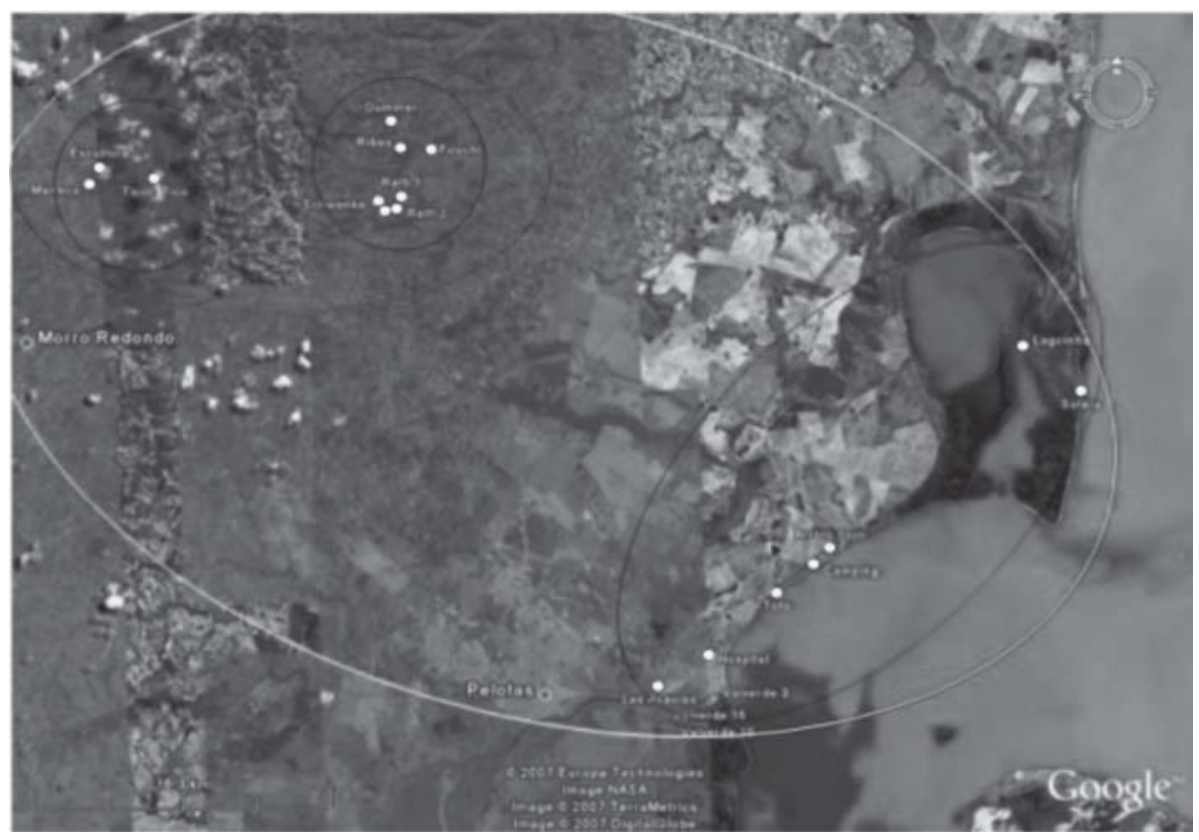

Fig. 13. Mapa com localização dos sítios arqueológicos no litoral e serra, demonstrando o contexto regional a partir do conjunto de sítios e o contexto macro-regional que caracteriza o teko'á do arroio Pelotas.

Considerando-se esta correlação sistêmica entre o assentamento litorâneo e serrano ficam as perguntas: quais os fatores que estariam envolvidos na estratégia de assentamento Guarani nessas diferentes áreas? Por que os grupos Guarani, assentados na região serrana, teriam ocupado o litoral em busca de novas áreas de moradia?

Segundo Brochado (1984), os grupos Guarani expandem seu território de domínio lentamente de forma radial a partir de um ponto central. Essa forma de expansão ficou conhecida como "enxameamento", em que o território pode ser dominado ou expandido sob vários modos, como por exemplo, guerras, alianças políticas, fortalecimento das relações familiares, guaranização, cuñadazgo etc.

(Noelli 1993, 2004; Assis 1996; Soares 1997). Vários fatores determinam a expansão territorial, os quais são relacionados aos aspectos culturais, sociais, econômicos, políticos e simbólicos: a) as relações de reciprocidade, embasadas na estrutura social de parentesco e alianças políticas que, por um lado, permitem a aquisição de prestígio pelas lideranças, famílias e suas respectivas aldeias e, por outro lado, permitem a continuidade cultural e o modo de ser Guarani (ñande reko); b) crescimento demográfico, fator que gera a divisão de aldeias e força a necessidade da aquisição de novas terras para assentamento; c) pressão populacional causada por grupos inimigos, sejam eles Guarani ou não-Guarani que podem estar relacionados a problemas de fronteiras; d) escassez de recursos ambientais na área de domínio, fator esse que gera a necessidade de adaptação a novas áreas ecológicas; e) esgotamento das terras cultivadas pela horticultura; f) a busca da "terra sem males" (yvy marane'y).

Todos estes fatores podem ter condicionado o processo de ocupação Guarani na região de estudo. No modelo de expansão e ocupação regional em discussão sugerimos que os sítios do interior, por serem mais antigos, se situarem na área de cobertura vegetal de floresta tropical, em terras de maior potencial agrícola e próximos dos melhores e mais abundante recursos ambientais, constituam o centro do sistema de assentamento. Em 
contrapartida, os sítios litorâneos, mais recentes, ocupam uma área periférica do território, onde os recursos tradicionalmente explorados pelos grupos Guarani na serra são mais escassos, de forma que possa ter havido um esforço social significativo para a captação de diferentes recursos litorâneos, havendo inclusive uma adaptação ao ambiente lacustre e a instauração de uma política fronteiriça amistosa com os grupos cerriteiros. ${ }^{8}$

Neste sentido, consideramos que o assentamento litorâneo seja uma extensão do teko'á, que comporta o excedente populacional das aldeias mais antigas e centrais do interior. No litoral teríamos sítios com menor densidade populacional que, em conseqüência, geraria menor densidade de vestígios materiais no registro arqueológico. Esta parece ser a mesma percepção de Soares (1999: 129) ao aplicar seu modelo de organização social e espacial em ocupações do interior do Rio Grande do Sul. "Os sitios nos vales encaixados (ou em nosso caso, no litoral) por possuirem menor representatividade social, poucas alianças, família extensa pouco numerosa, menor número de vassalos/colaboradores, são 'jogados' ou empurrados para as zonas limítrofes do teko'á (...). Um sítio como este deve caracterizar-se por pouca incidência de grandes vasilhames (devido à ausência de grandes festas e baixa densidade demográfica por família), casas menores (menor população), (...) Os sitios grandes, ao contrário, apresentam boa quantidade de 'cacos' cerâmicos de grande porte (sinal de vasilhas grandes para grandes familias e festas contíguas ou repetidas), casas de proporções também grandes (que representam as famílias extensas), grandes concentrações de material

(8) Aqui tocamos num assunto não explorado neste texto. Os montículos de terra conhecidos como cerritos são muito abundantes na região de estudo. Através de nossa pesquisa foi possivel identificar 16 novos sítios na região do banhado do Valverde, exatamente na ligação entre a Laguna dos Patos e o canal São Gonçalo, muito próximos das áreas de ocupação Guarani. Nas visitas a estes cerritos pudemos constatar a presença de cerâmica com decoração tipicamente Guarani em alguns fragmentos que apontam para processos de interação entre estes dois grupos (cf. Rogge 2004). arqueológico e profundidade das 'manchas pretas' que caracterizaria uma longa ocupação do território." 9

Um outro fator cultural deve ser levado em consideração, que diz respeito às relações sociais entre as aldeias tanto do litoral como do interior. Propomos, com base nos modelos etnoarqueológicos, que as relações de reciprocidade fossem freqüentes entre os assentamentos de ambas as regiões (ver Brochado 1984; Noelli 1993; Assis 1996; Soares 1997). Diversas formas de relações de reciprocidade são compreendidas na sociedade Guarani. Soares (1997) discorre sobre algumas delas, como, por exemplo, os festins cerimoniais para casamentos e rituais de passagem, convites para trabalho comunal, guerras entre grupos e subseqüente apaziguamento que gera ou fortalece alianças etc.. As relações de reciprocidade, além de fortalecerem as relações de amizade, parentesco e alianças, permitem a continuidade cultural e a estruturação do modo de ser Guarani, já que a socialização e a troca cultural são aspectos reforçados constantemente, que se concretizam na língua, cultura material e organização social e espacial.

As relações de reciprocidade são essencialmente coletivas e têm início através de convites (pepy, 'festa, convite') entre as aldeias seja para uma caça ou pescaria coletiva, seja para abrir uma roça ou para comer e beber em festas comunais. Essas atividades coletivas conhecidas como potyro ou puxirão estreitam as relações de amizade, parentesco e reciprocidade e se concretizam através de convites que, por sua vez, criam e reforçam a socialização e a coletividade Guarani, sendo grande a honra do çoó - 'ser convidado', e ainda maior no ato de convidar: caruguaçu 'convite para comer'” (Soares 1999: 142). Este convite para comer segue primeiro a disponibilidade da comida, pois da quantidade dependerá

(9) Note-se que o autor fala de sítios relacionados entre si que se situam em vales. Na presente pesquisa refletimos sobre a relação sistêmica entre a serra e o litoral, o que configura ambientes distintos do proposto por Soares (1999). Porém, mesmo em se tratando de casos distintos, acreditamos ser válido esse modelo sugerido pelo autor na aplicação da pesquisa em questão. 
a abrangência social do convite da família à região. O primeiro passo é o caruguaçu amonã - 'fazer convite', que seguirá conforme o evento que está em andamento, fazer uma casa, uma roça ou convite para casamento. ${ }^{10}$

Neste sentido, percebe-se que os convites e as atividades coletivas fortalecem os laços de reciprocidade entre aldeias, sendo um aspecto que amplia o grau de prestígio da aldeia e de suas lideranças. Além disso, as atividades coletivas que geram visitações entre aldeias de um mesmo ou de diferentes teko'á são fatores importantes para a sustentação econômica dos grupos. Através dessas visitações, possivelmente acompanhadas de artigos para comercialização ou trocas de presentes, podemos imaginar que o assentamento litorâneo possa suprir suas necessidades com relação a determinados tipos de materiais ausentes na região praial, como é o caso, por exemplo, do material lítico. ${ }^{11}$

Levando em consideração essas relações de prestígio social, os sítios serranos podem ser vistos, nesse caso, como a parte do sistema de assentamento mais antiga e tradicional, onde as lideranças tenham maior prestígio social. É a porção do teko'á onde habitam os caciques de maior influência regional, os quais determinam ou influenciam significativamente nas escolhas de novos assentamentos, o que origina a expansão do território de domínio. No litoral, por sua vez, seria a porção do teko'á mais recentemente ocupada, não se configurando como um espaço tradicionalmente ocupado. Apesar disso, a possibilidade em explorar os recursos lacustres parece ser um fator importante, que talvez tenha influenciado na escolha deste local para a expansão do assentamento. Com a exploração

(10) "Em nível de teko’á, podendo talvez ser expandido ao guará, a honra de 'comer no mesmo prato' e seu papel social podem ser percebidos nos convites mais abrangentes, no caso em que se convidam outras aldeias para os festins de cauinagens, rituais antropofágicos e outras festas que envolvem excedente de produção agrícola" (Soares 1997: 145).

(11) Por outro lado, imagina-se que materiais litorâneos, ausentes na região serrana, poderiam ser cambiados da mesma forma, porém, não podemos avançar nesse aspecto devido à falta de vestígios indicativos dessa relação. desses recursos uma nova rede de troca de bens materiais surge, integrando o litoral e a serra, o que faz com que a porção litorânea do território passe a ter fundamental importância no sistema de assentamento, surgindo assim novas lideranças, que, por sua vez, dão continuidade ao processo de expansão aumentando seus domínios em torno da Laguna dos Patos, estabelecendo novas relações de contato e fronteiras com os grupos Guarani e não-Guarani, como os cerriteiros.

O padrão de distribuição e as datas dos sítios arqueológicos são elementos que devem ser considerados também para a proposição deste modelo. Ao analisarmos o mapa de distribuição dos sítios, fica claro que a porção serrana do território de domínio tem um padrão de distribuição dos sítios arqueológicos aglomerados, formando clusters densos na paisagem. Este padrão de distribuição de sítios verificado está de acordo com o padrão de assentamento esperado para sítios Guarani em paisagens com relevo, zonas de interflúvio e em meio a florestas tropicais. Os sítios se localizam em topo de morro e meia encosta, em confluência de rios e arroios muito próximos uns dos outros (ver, por exemplo, Schmitz 1985, 2006 [1991]; Noelli 1993, 2004; Rogge 1995-1996; Dias 2003; Soares 1997, 1999; Fausto 2001). Esta é, portanto, uma forma tradicional de ocupação do espaço, em que a expansão vai se dando em duas escalas de tempo e espaço.

Uma escala de ocupação de um amplo espaço, que se dá de forma lenta e gradual, na medida em que se estabelece o sistema de expansão do território Guarani por "enxameamento" para novos ambientes, ampliando, por sua vez, o território de domínio. Esse processo pode dar-se através de várias gerações em escalas espaciais ainda não medidas pela arqueologia. Nessa escala, novos territórios são acoplados ao território conhecido, novas regiões vão sendo conhecidas e mapeadas ao longo do tempo, novas áreas de captação de recursos vão sendo exploradas e uma nova constituição cognitiva do espaço vai sendo construída (Posey 1986; Zedeño 1997, 2000). Durante o processo de reconhecimento e dominação do território, grupos de menor prestígio, com lideranças menos influen- 
tes, vão sendo "empurrados" e, na medida em que o espaço vai se tornando conhecido e tradicional, a ocupação tende a se tornar mais densa e mais importante dentro do sistema de assentamento (Soares 1997).

Dentro deste processo de expansão ampla e lenta, ocorre uma expansão em uma outra escala mais rápida e com menor amplitude espacial. Isto se dá quando ocorre o abandono das aldeias, ocupando-se novas aldeias dentro do território ou mesmo retornando-se para as aldeias antigas. Este processo se desencadeia em média, dentro de três a cinco anos, mas pode dar-se a qualquer momento, por motivos variados. ${ }^{12}$ As trajetórias de "idas e vindas" dentro do território de domínio, relativas à ocupação e reocupação de aldeias não pode ser medida em nosso trabalho pela ausência de datações de todos os sítios da serra, mas sugerimos, como hipótese, que tenha se dado de forma "centrípeta", assim como proposto por Schmitz (1985) para os sítios no vale do Médio e Alto Jacuí-RS. Entretanto, diferentemente do modelo de Schmitz (1985), que considera apenas a presença de uma ou duas aldeias movimentandose no território, consideramos que possamos estar frente a um sistema multi-aldeão, que se caracteriza pela fragmentação política das lideranças em mais de uma aldeia, mas, ainda assim, com a manutenção da unidade sociológica que caracteriza o sistema de assentamento (Fausto 2001). Este sistema de ocupação territorial "centrípeto" sugere a ocupação e reocupação do mesmo espaço ao longo de gerações em uma situação de "circunscrição social e territorial” (cf. Fausto 2001; Lima \& López Mazz 1999-2000), em que a unidade sociológica se mantém coesa, gerando a manu-

(12) Segundo Fausto (2001), este tipo de deslocamento é classificado como de média distância, implicando no abandono de aldeias e roças e a mudança para longe, mas dentro de uma região plenamente conhecida. O abandono das aldeias dos Parakanãs orientais, segundo o autor, se dá em média dentro de três anos e pode ocorrer por razões mais variadas, desde a morte de crianças, ataque de inimigos, conflito interno, ausência de roça, até a presença exagerada de pulgas. tenção das relações de reciprocidade e privilégios nas aldeias e entre elas, a partir da permanente interação social, política, econômica e cultural. É, portanto, a partir da "circunscrição social" e da manutenção de redes de relações de reciprocidade que se mantém a estrutura social, o modo de ser Guarani (ñande reko), bem como comenta Noelli (2004: 24): "Las redes regionales y la estructura politica y social de alianzas, sostenidas por el intercambio permanente, explica la reproducción constante da la cultura material y otros rasgos del ñande rekó Guarani"

Este modelo de interpretação pode ser pensado para entendermos o processo de ocupação litorâneo e a ocupação na serra. Entendemos que o processo de expansão territorial tenha se dado de forma "radial" do centro do assentamento (Serra do Sudeste) para a periferia (litoral). Esta percepção se dá porque o padrão de distribuição das aldeias na serra sugere uma situação de "circunscrição social e territorial", indicando se tratar de um sistema de assentamento tradicional e antigo, o que é sugerido também pela data do sítio PSGPA-04Ribes, com idade de $510 \pm 70$ A.P. Por outro lado, no litoral, o padrão de distribuição dos sítios demonstra uma situação de contemporaneidade e mais recente implantação, relativa ao reconhecimento e início da dominação do território. Novas áreas vão sendo ocupadas lenta e gradualmente, permitindo pensar no litoral como um território que vai sendo anexado ao território de domínio Guarani original, o que é indicado também pelas datações dos sítios do litoral (Sítio PS-03-Totó, com idade de $530 \pm 40$ AP e Sítio PS-02-Camping, com idade de $380 \pm 50 \mathrm{AP}$ ). Ao mesmo tempo em que ocorre este deslocamento "radial" do interior para a periferia, consideramos que os deslocamentos "centrípetos", referentes à ocupação e reocupação das aldeias do interior sejam constantes, garantindo a permanência de redes sociais de reciprocidade e, por conseguinte, mantendo a estrutura social e o modo de ser Guarani.

Este sistema de expansão centro/periferia pode ser considerado também em nível mais amplo, abrangendo todas as áreas de ocupação Guarani no estado do Rio Grande do Sul. Sabemos que grande parte do estado foi ocupa- 
da pelos grupos Guarani, pois, com exceção da região da campanha e dos campos do nordeste do estado, todas as outras regiões foram dominadas (Noelli 2004). Sabe-se que esses grupos tiveram deslocamentos expansionistas de norte para sul e de leste para oeste, seguindo as regiões de várzeas férteis dos médios e grandes afluentes dos Rios Uruguai, Ijuí e Jacuí (Rogge 2004). As datações nestas regiões chegam até 1800 A.P., no centro do estado e até 1300 e 1000 A.P., em diferentes locais (Noelli 2004).

Num segundo momento de expansão territorial as populações Guarani se voltaram para a região da Serra do Sudeste, por volta de 500 AP. (como indicado pela data do sítio Ribes), mas num determinado momento ainda não compreendido, passaram a ocupar as regiões das lagoas e lagunas do litoral do estado, o que se deu em torno de 900 A.P. (Noelli 19992000; Rogge 2004; Schmitz 2006 [1991]), até a colonização européia, quando este quadro muda radicalmente em função de todo impacto etnocida que a colonização causou sobre as populações indígenas: doenças contagiosas, escravização, matança, descaracterização cultural, roubo de terras etc. (Brochado 1984; Schmitz 2000, 2006 [1991]; Noelli 1993, 1999. 2000).

As datas de ocupação do litoral como um todo demonstram uma ocupação tardia, mas sugerem um processo articulado, entre assentamentos de diferentes regiões, em busca de novos territórios de domínio. Nota-se isto através da sistematização de datas químicas de sítios Guarani ao longo do litoral, que demonstram que este processo de expansão, que parte das terras altas do interior em direção às terras baixas do litoral, tenha se dado num mesmo horizonte cronológico. Neste sentido, as datas do Sítio Camping e Totó vêm a reforçar que o processo de ocupação Guarani da região lagunar tenha se dado num período já relativamente próximo da colonização européia no Brasil, tendo sido barrado pelas atividades etnocidas a partir do século XVI. Sobre isso, é importante destacar que se trata de um processo de longa duração que envolve estratégias de dominação territorial, por parte dos grupos Guarani, em ocupar o litoral, visto que esse processo se deu num período de mais de 500 anos em que os grupos passaram a ocupar a borda da Laguna dos Patos. Quando se dá a chegada dos europeus, as sociedades indígenas Guarani já estavam estabelecidas na zona litorânea, em pleno processo histórico de articulação inter-cultural e expansão territorial. Logo, considerar que esse processo é recente e teve como fator original a colonização e a exploração européia no interior do estado, como querem alguns historiadores, seria desconsiderar todo um cabedal de informações arqueológicas e etnológicas constituídas nos últimos 40 anos.

\section{Considerações finais}

Ao apresentar este modelo interpretativo de ocupação regional Guarani, buscamos articular dados arqueológicos, etnohistóricos e etnográficos, no intuito geral de dar significado social e histórico à estática do registro arqueológico (Binford 1980; 1991 [1983] Schiffer 1987).

Buscamos lançar um novo olhar sobre a arqueologia Guarani, abordando discussões que dizem respeito aos aspectos culturais numa perspectiva holística, em que foram levados em consideração conceitos de territorialidade, organização social, relações de parentesco, alianças políticas e estratégias de ocupação espacial e anexação de territórios. Desta forma, acreditamos ter ultrapassado a abordagem meramente descritiva dos dados arqueológicos, atingindo uma estrutura sistêmica e interpretativa mais ampla.

Com o desenvolvimento deste modelo interpretativo, vários problemas de pesquisa surgem como rumo para pesquisas futuras. Várias questões ficam em aberto, sem condições de serem respondidas no momento em virtude da incipiência dos trabalhos arqueológicos na região e do alto grau hipotético do próprio modelo. Enfatizamos que ainda são escassos os dados relativos à cronologia regional, mapeamento de outras áreas de ocupação, refino do mapeamento da área já inicialmente estudada, escavação de sítios em áreas amplas para compreensão da organização espacial intra-sítio, estudos de demografia regional e um diagnóstico mais apurado das relações sociais entre os grupos 
Guarani e não-Guarani. Neste sentido, sugere-se que o modelo sirva de base para pesquisadores futuros que venham a contribuir para o desenvolvimento de uma história Guarani de longa duração na porção meridional da Laguna dos Patos e na Serra do Sudeste.

\section{Agradecimentos}

Agradeço imensamente à Profa. Dra. Elaine Farias Veloso Hirata (MAE-USP) pela sensibilidade com que orientou este trabalho de pesquisa. Ao Prof. Dr. Paulo DeBlasis (MAE-USP) pelas inspirações teóricas e ricas leituras críticas que rechearam esta pesquisa, e ao Prof. Dr. Fábio Vergara Cerqueira (LEPAARQ-UFPEL) pelo apoio incondicional concedido em termos de logística e suporte financeiro. Agradeço também a todos os colegas do LEPAARQ-UFPEL e de outras instituições que auxiliaram nos trabalhos de campo e laboratório de forma exaustiva e exemplar.

MILHEIRA, R.G. A model of Guarani regional occupation in southern Brazil. Revista do Museu de Arqueologia e Etnologia, São Paulo, 18: 19-46, 2008.

Abstract : This paper shows a study of regional archaeology, aiming to understand the systemic relations of Guarani occupation at the Laguna dos Patos southwest border and the southeast mountain range (Serra do Sudeste) southern Brazil. With a regional perspective and taking in consideration the conservation and locational conditions, this study focuses on regional distribution of sites, their internal structures and artifactual assemblages. In order to disclose territorial patterns of occupation and their archaeological settlement distribution, tecno-tipological analysis systematization, sites composition and ethnographic and ethnohistorical information has allowed building up a long duration historical perspective revealing the Guarani social web maintenance strategies and intercultural contacts within a territory dominion, articulating distinct environmental strata of the region.

Keywords: Guarani Archaeology - Regional Archaeology - Settlement system - Dominion territory - Social organization.

\section{Referências bibliográficas}

ARAUJO, A.G.M.

2001 Teoria e Método em Arqueologia Regional: Um estudo de caso no Alto Paranapanema, Estado de São Paulo. Tese de Doutorado, São Paulo: USP.

ASSIS, V.S.

1996 Da Espacialidade Tupinambá. Dissertação de Mestrado, Porto Alegre: PUCRS.

BINFORD, L.R.

1979 Organization and formation process: looking at curated technologies. Journal of Anthropological Research, 35 (3): 269-286.

1980 Willow smoke and dog's tails: huntergatherer settlement systems and archaeological site formation. American Antiquity, 45 (1): 4-20.

1991 Em busca do Passado. s.l.: EuropaAmérica, [1983].

BROCHADO, J.P.

1974 Pesquisas Arqueológicas no Escudo 
Cristalino do Rio Grande do Sul (Serra do Sudeste). Publicações Avulsas do Museu Paraense Emilio Göeldi, 26 (PRONAPA 5). Belém: MPEG: 25-51.

1984 An Ecological Model of the Spread of Pottery and Agriculture Into Eastern South America. Tese de Doutorado. Carbondale: University of Illinois at Urbana-Champaign.

BROCHADO, J.P.; MONTICELLI, G.; NEUMANN, E.

1990 Analogia etnográfica na reconstrução gráfica das vasilhas Guarani arqueológicas. Veritas, 35 (104), dez.: 727-743.

BROCHADO, J.P.; MONTICELLI, G.

1994 Regras práticas na reconstrução gráfica das vasilhas de cerâmica Guarani a partir dos fragmentos. Estudos Ibero-americanos. Porto Alegre, XX (2), dez.: 107-118.

CARLE, M.B.

2002 Investigação arqueológica em Rio Grande: uma proposta da ocupação Guarani pré-histórica no Rio Grande do Sul. Dissertação de Mestrado, Porto Alegre: PUCRS.

CERQUEIRA, F.V.; LOUREIRO, A.G.

2004 Relatório do Mapeamento Arqueológico de Pelotas e Região (Atividades desenvolvidas entre março/2002 e fevereiro/ 2003). Cadernos do LEPAARQ, 1 (1): 87 108.

DIAS, A.S.

2003 Sistemas de Assentamento e Estilo Tecnológico: Uma Proposta Interpretativa para a Ocupação Pré-Colonial do Alto Vale do Rio dos Sinos, Rio Grande do Sul. Tese de Doutorado, São Paulo: USP.

FAUSTO, C.

2001 Inimigos Fiéis. História Guerra e Xamanismo na Amazônia. São Paulo: EDUSP.

FISH, S.K.; KOWALEWSKI, S.A. (Eds.)

1990 The Archaeology of Regions. A Case for Full Coverage Survey. Washington: Smithsonian Institution Press.

FISH, S.

1999 Conclusions: the Settlement Pattern Concept from an American Perspective. In: Brian, R.B.; Feinman, G.M. (Eds.) Settlement Pattern Studies in the Americas. Washington, Smithsonian Institution Press: 203-208.

HECKENBERGER, M.; FRANCHETTO, B. (Orgs.) 2001 Os Povos do Alto Xingu. História e Cultura. Rio de Janeiro: UFRJ.

JACOBUS, A.L.

1994 Vasilhas cerâmicas guarani arqueológicas em estruturas funerárias. Monografia, Porto Alegre: PUCRS.

LA SALVIA, F.; BROCHADO, J.P.

1989 Cerâmica Guarani. Porto Alegre: Posenato $\&$ Cultura.

LIMA, T.A.; LÓPEZ MAZZ, J.

1999-2000 La emergencia de complexidad entre los cazadores recoletores de la costa atlântica meridional sudamericana. Revista de Arqueologia Americana. Instituto Panamericano de Geografia e História, 17, 18, 19: 130-175.

MÉTRAUX, A.

1948 O Índio Guarani. HandBook of South American Indians - The tropical forest tribes. Smithsonian Institution, Washington, v.

3. Traduzido por Dante de Laytano.

MILHEIRA, R.G.

2007a Em busca de um contexto regional de ocupação guarani na margem sudoeste da Lagoa dos Patos. Anais do XIV Congresso da Sociedade de Arqueologia Brasileira. Florianópolis: UFSC.

2007b "Na Boca da Lagoa". Uma reflexão etnoarqueológica das atividades de pescadores na Ilha da Feitoria, PelotasRS. Revista do CEPA, no prelo.

2008 Território e Estratégia de Assentamento Guarani na Planície Sudoeste da Laguna dos Patos e Serra do Sudeste - RS. Dissertação de Mestrado, São Paulo: MAE-USP.

MONTICELLI, G.

1995 Vasilhas Cerâmicas Guarani: um resgate da memória entre os Mbyá. Dissertação de Mestrado, Porto Alegre: PUCRS.

MORAIS, J.L.

1999-2000 Arqueologia da Região Sudeste. Revista da USP, 44: 194-217.

MORALES, W.F.

200512.000 anos de ocupação: Um estudo de Arqueologia Regional na Bacia do Córrego Água Fria, médio curso do Rio Tocantins. Tese de Doutorado, São Paulo: USP.

NAUE, G.; SCHMITZ, P.I.; BASILE-BECKER, Í. I.

1968 Sítio arqueológicos no município de Rio Grande. Pesquisas-Antropologia, 18, São Leopoldo, Instituto Anchietano de Pesquisas-UNISINOS: 141-152.

NAUE, G.; SCHMITZ, P.I.; VALENTE, W.; BASILE BECKER, I.I.; LA SALVIA, F.; SCHORR, M.H.

1971 Novas perspectivas sobre a arqueologia de Rio Grande-RS. Revista do Instituto de Préhistória. São Paulo: 91-122. 
NEVES, E.G.

1999 Twenty years of Amazonian archaeology. Antiquity, 72 (277): 625-632.

NOELLI, F.S.

1993 Sem Tekohá não há Tekó (em busca de um modelo etnoarqueológico da subsistência e da aldeia Guarani aplicada a uma área de domínio no delta do Jacui-RS). Dissertação de Mestrado, Porto Alegre: PUC-RS.

1999-2000 A ocupação humana na região sul do Brasil: arqueologia, debates e perspectivas - 1872/2000. Revista da USP, São Paulo, 44: 218-269.

2004 La distribución geográfica de las evidencias arqueológicas Guaraní. Revista de Indias, Madrid, LXIV (230) enero-abril: 17-34.

NOVAES, S.C. (Org.)

1983 Habitações Indígenas. São Paulo: EDUSP.

ORTON, C.; TYERS, P.; VINCE A.

1993 Pottery in Archaeology. London: University Press; Cambridge: Cambridge University Press.

PALLESTRINI, L.; MORAIS, J.L.

1984 Prassévichus: aldeia pré-histórica no Município de Itaberá, SP. Revista do Museu Paulista, Nova Série, XXIX: 151-167.

PERNIGOTTI, O.; ALMEIDA, Á.N.

1961 Depósitos Arqueológicos do Município de Rio Grande, mimeo.

PESTANA, M.B.

2007 A Tradição Tupiguarani na Porção Central da Planície Costeira do Rio Grande do Sul, Brasil. Dissertação de Mestrado, São Leopoldo: UNISINOS.

POSEY, D.A.

1986 Manejo da Floresta Secundária, Capoeiras, Campus e Cerrados (Kayapó). In: Ribeiro, D. (Ed.) Suma Etnológica Brasileira V. 1 - Etnobiologia. Rio de Janeiro: 173-188.

RADAMBRASIL

1986 Levantamento de Recursos Naturais da secretaria do Planejamento da Presidência da República. IBGE, v. 33.

REDMAN, C.

1973 Multistage fieldwork and analytical techniques. American Antiquity, 38 (1): 61-79.

RIBEIRO, P.A.M.; PENHA, M.A.P.; FREITAS, S.E.; PESTANA, $M$.

2004 Levantamentos Arqueológicos na Porção Central da Planície Costeira do Rio Grande do Sul, Brasil. Revista de Arqueologia, SAB, 17: 85-100.
ROBRAHN-GONZALEZ, E.M.

1988 A Ocupação Pré-Colonial do Vale do Ribeira de Iguape, SP: Os Grupos Ceramistas do Médio Curso. Dissertação de Mestrado, São Paulo: USP.

ROGGE, J.H.

1995-1996 As teorias adaptacionistas e o estudo de grupos horticultores - A tradição tupiguarani no médio rio Jacuí. Anais da VIII Reunião Científica da PUCRS. Coleção Arqueologia, v. 1 (1). Porto Alegre, EDIPUCRS: 245-254.

1997 Função e permanência em assentamentos litorâneos da tradição tupiguarani: um exemplo do litoral central do Rio Grande do Sul. Anais do IX Encontro da Sociedade de Arqueologia Brasileira. Rio de Janeiro.

2004 Fenômenos de Fronteira: Um Estudo das Situações de Contato entre Portadores das Tradições Cerâmicas Pré-históricas no Rio Grande do Sul. Tese de Doutorado, São Leopoldo: UNISINOS.

ROSA, M.

1985 Geografia de Pelotas. Pelotas: UFPEL.

RYE, O.S.

1981 Pottery Technology. Principles and Reconstruction. Washington D.C.: Taraxacum.

\section{SCHMITZ, P.I.}

1976 Sítios de pesca lacustre em Rio Grande, RS, Brasil. Tese de Livre Docência, São Leopoldo: Instituto Anchietano de Pesquisas.

1985 Território de domínio em grupos TupiGuarani. Considerações sobre o médio e alto Jacuí, RS. Boletim do MARSUL, Taquara, 3, novembro: 45-52.

2000 O Guarani: História e Pré-história. In: Tenório, M.C. (Org.). Pré-história da Terra Brasilis. UFRJ: 285-292.

SCHMITZ, P.I. (Org.)

2006 Pré-história do Rio Grande do Sul. Documentos, 5. São Leopoldo: Instituto Anchietano de Pesquisas [1991].

2006 A ocupação Pré-histórica do litoral meridional do Brasil. Pesquisas, 63.

SHAPIRO, G.

1984 Ceramic vessels, site permanence and group size: a Mississippian example. American Antiquity, 49 (4): 696-712.

\section{SCHIFFER, M.B.}

1987 Formation Processes of the Archaeological Record. Albuquerque: University of New Mexico Press.

SHEPARD, A.O.

1985 Ceramics for the Archaeologist. Washington 
Um modelo de ocupação regional Guarani no sul do Brasil .

Revista do Museu de Arqueologia e Etnologia, São Paulo, 18: 19-46, 2008.

D.C.: Carnegie Institution of Washington [1956].

SOARES, A.L.R.

1997 Guarani. Organização Social e Arqueologia. Porto Alegre: EDIPUCRS.

1999 Horticultores Guaranis: Modelos, Problemáticas e Perspectivas. Revista do CEPA, Santa Cruz do Sul, UNISC, 23 (30):103-141.

2005 Contribuição para a Arqueologia Guarani. Tese de Doutorado, São Paulo: USP.

TOMAZELLI, L.J.; VILLWOCK, J.A.

2000 O Cenozóico no Rio Grande do Sul:
Geologia da Planície Costeira. In: Holz, M.; De Ros, L.F. (Eds.) Geologia do Rio Grande do Sul. Porto Alegre: CIGO/ UFRGS.

ZEDEÑO, M.N.

1997 Landscapes, land use, and the history of territory formation: an example from puebloan southwest. Journal of Archaeological Method and Theory, 4 (1): 63-103.

2000 What People Make of Places. A Behavioral Cartography. In: Schiffer, M. B. (Ed.)

Social Theory in Archaeology. Utah: University of Utah Press: 97-111.

Recebido para publicação em 10 de setembro de 2008. 